
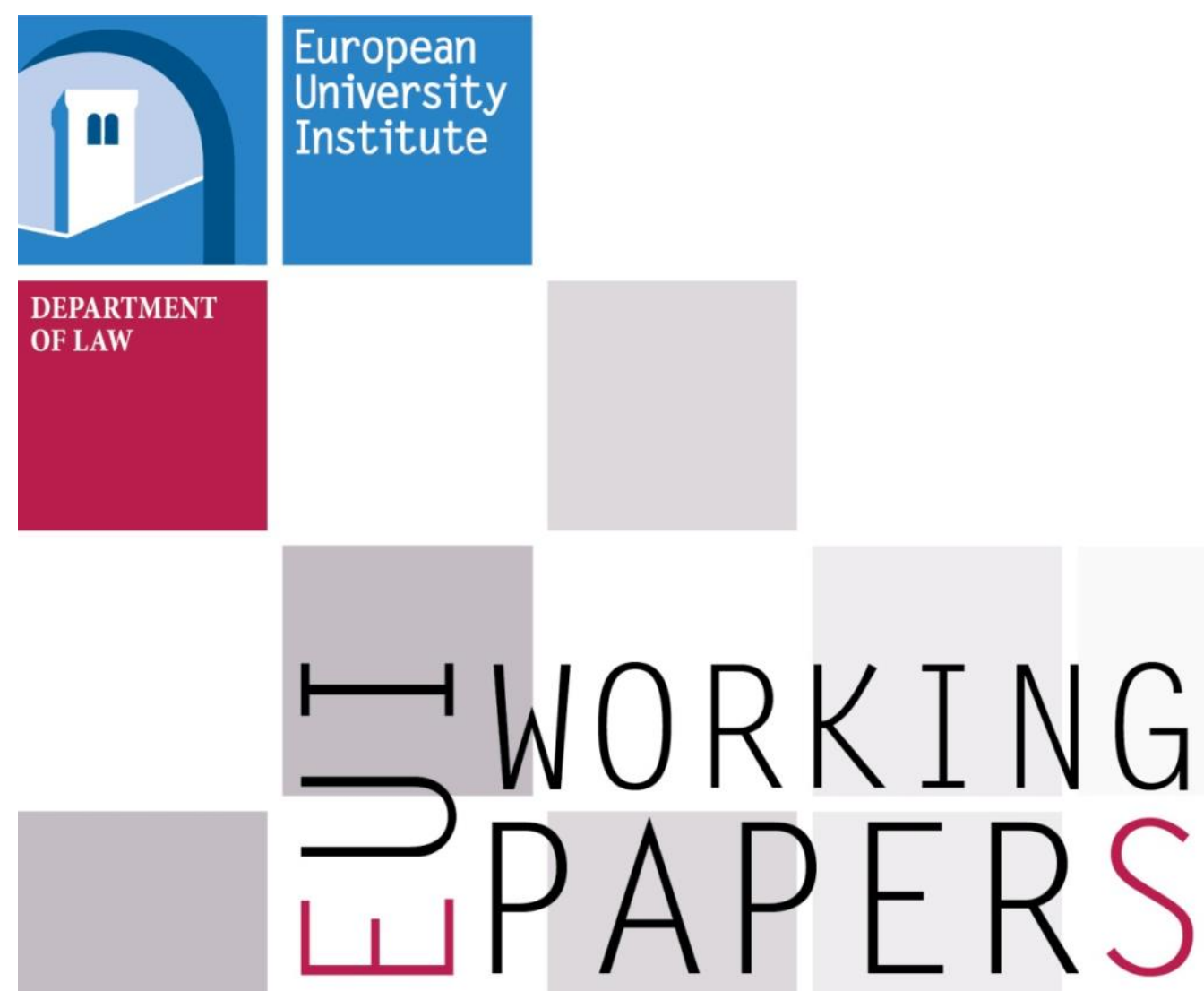

LAW 2018/05

Department of Law

No GATS no glory: The EU regulation of clearinghouses and WTO law

George A. Papaconstantinou 

European University Institute

Department of Law

\section{No GATS No GLORY: THE EU REgUlation OF Clearinghouses aNd WTO LaW}

George A. Papaconstantinou

EUI Working Paper LAW 2018/05 
This text may be downloaded for personal research purposes only. Any additional reproduction for other purposes, whether in hard copy or electronically, requires the consent of the author. If cited or quoted, reference should be made to the full name of the author, the title, the working paper or other series, the year, and the publisher.

ISSN 1725-6739

(C) George A. Papaconstantinou, 2018

Printed in Italy

European University Institute

Badia Fiesolana

I-50014 San Domenico di Fiesole (FI)

Italy

www.eui.eu

cadmus.eui.eu 


\begin{abstract}
Following the 2008 financial crisis the EU reformed the regulatory regime pertaining to clearinghouses (or CCPs), and in particular the clearing of over-the-counter (OTC) derivatives. This paper evaluates whether the EU regime for CCPs is consistent with WTO Law and discusses how regulatory and market access (trade) objectives can be better managed. A number of problems of both procedural and substantive nature are identified with the EU regime for CCPs, and specifically the equivalence mechanism to assess third country clearinghouses (EMIR Art. 25), with onerous implications for many non-EU service suppliers seeking to provide their services inside the EU internal market. Smaller countries are less likely to have access to the EU market and to be negatively impacted by the EU regime.
\end{abstract}

Keywords: GATS, Trade in financial services, Clearing OTC derivatives, EU Regulation (EMIR)

JEL: G15, G18, G23, F23, F36 
Author contact details:

George A. Papaconstantinou

PhD Researcher

Law Department

European University Institute (EUI), Florence

Villa Salviati, Via Bolognese 126

50139 Florence - Italy

George.Papaconstantinou@eui.eu 


\section{Table of contents}

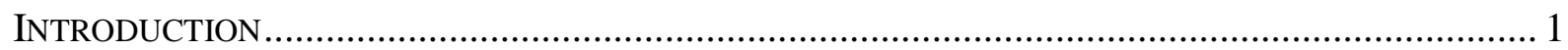

Clearing OTC DERIVATIVES: REgulatory IMPETUS FOR CENTRAL COUNTERPARTIES ........... 1

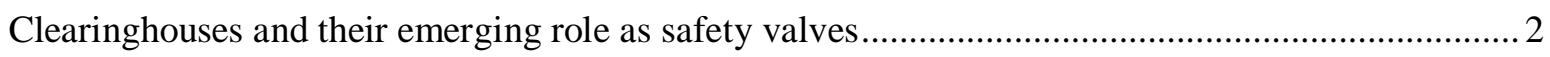

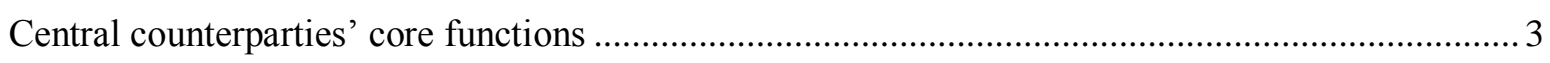

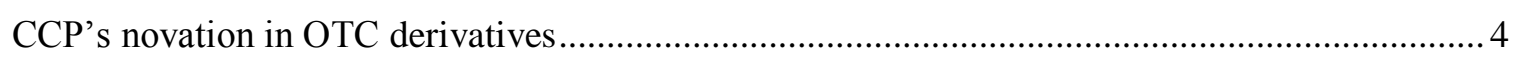

Internalizing counterparty risk and the systemic stability mandate ............................................ 4

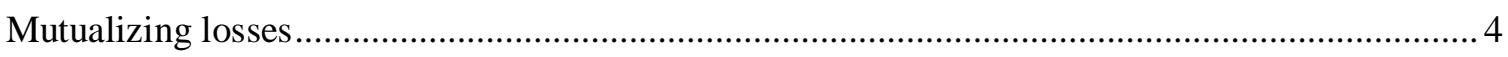

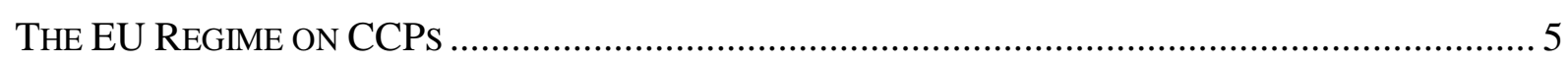

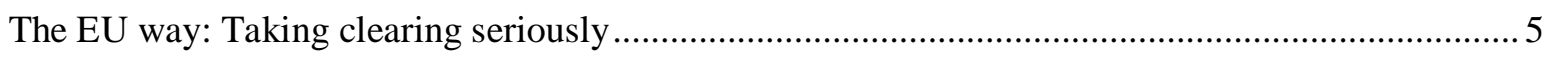

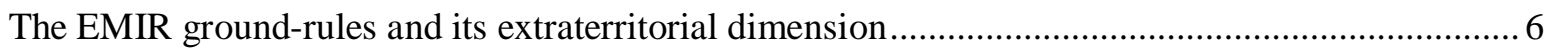

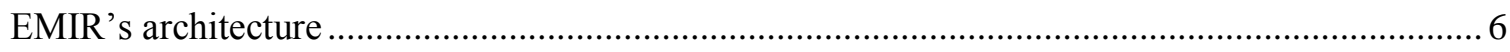

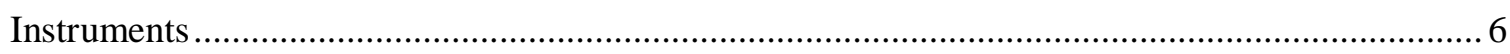

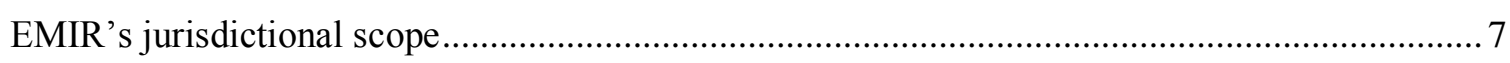

The 'equivalence' regime for third-country central counterparties ............................................... 8

Financial Regulation and International Economic Law: what's the catch? ..................................... 10

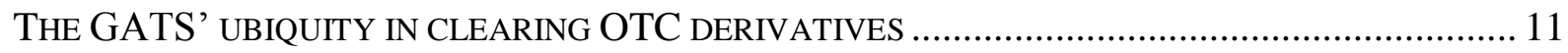

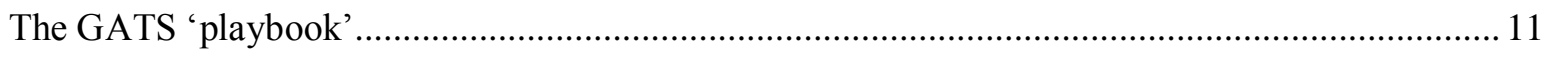

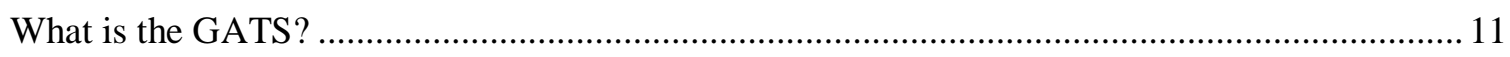

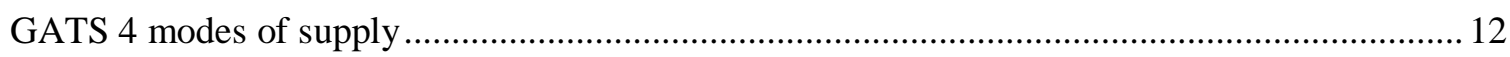

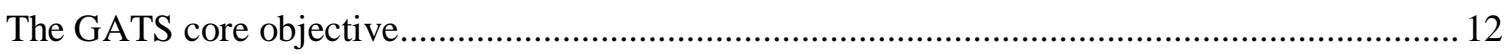

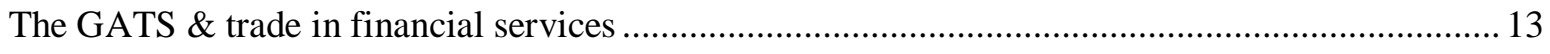

What is the Annex and the WTO jurisprudence take on clearing?............................................ 13

The Understanding and its crucial role for the EU commitments on financial services................. 14

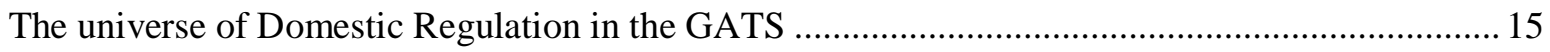

GATS Article VI: a pervasive trade-law tool (in hibernation) ................................................... 15

THE WTO LAW CONSISTENCY OF THE EU REGIME ON THIRD-COUNTRY CLEARINGHOUSES ...... 16

Cross-border supply vs Consumption abroad: the stakes for trade in clearing services ................... 16

Transparency: and its problematic aspects in 'third country's CCPs recognition process ................ 18

The European Commission's excessive discretion in the 'equivalence' determination .................... 20

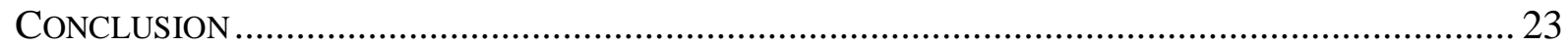





\section{Introduction}

In a globalized era, with financial transactions and contracts consummated everywhere, it is all the more important to interrogate the interrelation between domestic regulation and international integration. For instance, a financial transaction carried out on-exchange in London or over-the-counter in Singapore can and does have implications in every possible part of the world, for myriads of reasons. For financial markets the words certainty and confidence stand for something. Their opposites not only impinge on sectors that on the surface seem unrelated, but also on all the arrays of countries' economies. Their ramifications affect many constituencies, regardless whether these constituencies are involved in the transactions or not. That is one of the natural consequences of globalization and subsequently, of the degree of interconnectedness that financial markets around the globe have reached, as has been illustrated in numerous occasions on the last half a century.

EU financial regulation and WTO Law are selected as benchmarks to test the hypothesis of the interconnectivity of the separate legal disciplines because of their prominence in the world economy. Regulating financial services sectors is an undoubtedly challenging task because of the endogenous complexities and the fast pace of technological change. ${ }^{1}$ WTO rules constitute the external layer of financial firms' practice, since they delineate the framework for how trade in services is to be conducted among territories around the world. The WTO seeks to contribute to growth for world economies through trade liberalization, without undermining domestic legislation. Examining these two branches of law in tandem can contribute not only to gaining a broader understanding of how the world's financial systems are regulated, but at the same time to front-run prospective irregularities that could emerge in the absence of coordination between the two.

In this paper, I address the following question: Is the EU regulatory regime for clearinghouses consistent with the EU's legal obligations under the WTO? Investigating this matter is of relevance for two reasons: firstly, to delineate the stance of international economic law in respect of clearinghouses and the clearing of OTC derivatives business; and secondly, to identify an ambiguity under the GATS relating to scheduling of commitments for different modes of trading financial services that needs to urgently, for the sake of legal certainty, be clarified by WTO Members and/or the adjudicatory bodies. The analysis identifies a number of inconsistencies between the EU Regulation and WTO law and discusses the rationale and political economy that underpin these problems.

The paper is structured as follows: Section 2 discusses the relevance of clearinghouses for the resilience of financial markets in the aftermath of the global financial crisis. Section 3 analyses the EU regulatory framework on clearinghouses. The operation of clearinghouses, and their innate international nature, is a matter for domestic regulations, but also for WTO law, since trade in financial services is conducted under the GATS regime. Section 4 presents the relevant disciplines the relevant GATS rules for clearinghouses. Section 5 assesses the consistency of EU regulation with the GATS and argues there is a substantial 'clash of disciplines'. Section 6 concludes.

\section{Clearing OTC derivatives: Regulatory impetus for Central Counterparties}

The regulatory overhaul that was devised to address the root causes of the recent financial turmoil heavily relies on the operations and efficiency of financial market infrastructure institutions.

\footnotetext{
${ }^{1}$ Flash Boys demonstrates some of the regulatory issues that have gained impetus, based on the emergence of high-frequency trading (HFT), and gives food for thought about the design of the regulatory response in that phenomenon. See Lewis, Michael. 2014. Flash boys: a Wall Street revolt. For a critical law and economics assessment of the book's arguments see Merritt B. Fox, Lawrence R. Glosten, and Gabriel V. Rauterberg, "New Stock Market: Sense and Nonsense, The," Duke LJ 65 (2015): 191.
} 
Clearinghouses have proven to be resilient in under-stress conditions. ${ }^{2}$ But only the future will tell whether they have been adequately designed to deliver their new mandate to eliminate risks and preserve stability in the over-the-counter derivatives trading business. The first financial crisis of the $21^{\text {st }}$ century has largely been attributed to the trading of complex and volatile credit derivatives. ${ }^{3}$ The regulatory responses, ${ }^{4}$ around the world, for containing the risks associated with over-the-counter (or better known as OTC) derivatives trading, that has impacted not only on the solvability of financial institutions, but also on the world's real economy as well, ${ }^{5}$ have placed in their epicenter CCPs to process and settle these types of contracts. The financial regulatory reforms with respect to OTC derivatives and clearinghouses' new systemic role were triggered by the G-20 mandate that "all standardized OTC derivative contracts should be traded on exchanges or electronic trading platforms, where appropriate, and cleared through central counterparties by end-2012 at the latest. OTC derivative contracts should be reported to trade repositories. Non-centrally cleared contracts should be subject to higher capital requirements". ${ }^{6}$ These reforms aim principally to reduce the pertinent risks of trading and furnish transparency in the over-the-counter derivatives transactions. The EU, which is the focal point of this study, and the US have drafted their regulatory frameworks and implemented the G-20 commitment accordingly $;{ }^{7}$ Regulation on OTC derivatives, central counterparties and trade repositories, also known as European Market Infrastructure Regulation (EMIR), ${ }^{8}$ and Title VII of the Dodd-Frank Act (DFA), ${ }^{9}$ respectively.

\section{Clearinghouses and their emerging role as safety valves}

Clearinghouses are 'a set of institutional arrangements that are designed to enhance contractual performance'. ${ }^{10}$ These arrangements have been elaborated by the European Commission in the drafting of a competition decision. ${ }^{11}$ The core mandate that clearinghouses have been tasked with by the G20 OTC derivatives market overhaul originates in the idea that by utilizing the services of a $\mathrm{CCP}$, the results

${ }^{2}$ See an analysis of the role that LCH.Clearnet played in the Lehman default in 2008 Julia Lees Allen, "Derivatives Clearinghouses and Systemic Risk: A Bankruptcy and Dodd-Frank Analysis,” Stanford Law Review 64 (2012): 1087.

${ }^{3}$ Credit derivatives are types of contracts to buy and sell credit risk, which is derived from an underlying asset. See Frank Partnoy \& David A. Skeel, Jr., The Promise and Perils of Credit Derivatives, 75 U. CIN. L. REv. 1019 (2007). The role of financial innovation in the unravelling of the crisis is intertwined with the design and marketing of these financial instruments. See Viral V. Acharya \& Matthew Richardson, Causes of the Financial Crisis, 21 Critical Review 195 (2009).

${ }^{4}$ All Clear?, Economist, Apr. 7, 2012, http://www.economist.com/node/21552209; Clear and Present Danger, ECONOMIST, Apr. 7, 2012, http://www.economist.com/node/21552217; Gillian Tett, Insight: The Clearing House Rules, FIN. TIMES, Nov. 5, 2009, http://www.ft.com/cms/s/0/5874e922-cald-1 lde-a5b5-00144feabdcO.html.

${ }^{5}$ Financial Times, Rennison and Staffford (2016), Reforming the derivatives market: an explainer, available at https://www.ft.com/content/6b5e97e0-7029-11e6-9ac1-1055824ca907.

${ }^{6}$ G-20 Pittsburgh Summit, Leaders' Statement: The Pittsburgh Summit (2009), available at http://ec.europa.eu/archives/ commission_2010-2014/president/pdf/statement_20090826_en_2.pdf, paragraph 13.

${ }^{7}$ Without sensu stricto respecting the set deadline.

${ }^{8}$ Regulation (EU) No 648/2012 of the European Parliament and of the Council of 4 July 2012 on OTC derivatives, central counterparties and trade repositories.

${ }^{9}$ Dodd-Frank Wall Street Reform and Consumer Protection Act of 2010, Pub. L. No. 111-203, Title VII (codified in sections of 7 USC and 15 USC).

${ }^{10}$ Ed Nosal, Clearing over-the-counter derivatives, Federal Reserve Bank of Chicago Economic Perspectives, Vol.35, No. 4 (2011).

11 'Clearing means the process of establishing positions, including the calculation of net obligations, and ensuring that financial instruments, cash or both, are available to secure its exposures arising from those positions'. Commission Decision relating to Clearstream, Case COMP/38.096 - Clearstream (Clearing and Settlement) (July 2009) OJ C165/7. EMIR in Article 2(3) furnishes a definition: Central counterparty clearing: the process by which a third party interposes itself, directly or indirectly, between the transaction counterparties in order to assume their rights and obligations, acting as the direct or indirect buyer to every seller and the direct or indirect seller to every buyer. 
of institutions' potential defaults would not have systemic spillovers. By prescribing that OTC derivatives traders shall use the services of a clearinghouse, regulators have switched the costs of risk management and valuations of derivatives markets from the contracting parties to the CCP, which is responsible for calibrating its algorithms for the collateral calculations based on the derivatives' underlying values.

Clearinghouses have existed in the financial market infrastructure system of the EU and the US since the late nineteenth century. ${ }^{12}$ CCPs have historically been indispensable institutions for the completion of securities transactions, and the range of their activities extends to the clearing of both exchange-traded and bespoke off-exchange securities. The scope of the paper lies in examining the clearing of OTC derivatives transactions. ${ }^{13}$ As of June 2016, the notional value of the OTC derivatives markets was 544 trillion US dollars. ${ }^{14}$ OTC derivatives markets are non-centralized, and comprise privately negotiated and executed transactions. These markets are inherently transnational because of the international nature of the participants, and the volume and value of their contracts outweighs the exchange-traded derivatives markets. ${ }^{15}$ In such markets, the benefits for the transacting parties emanate from the fact that they can structure their contracts bearing in mind their own tailored needs, and accordingly calibrate the allocation of the risks involved in the trade on the basis of their risk-tolerance, their appetite for profit and particular investment strategies. When it comes to the contracts standardization, industry groups, such as the International Swaps and Derivatives Association (ISDA), the International Capital Market Association (ICMA), and the International Securities Lending Association (ISLA), have generated uniformity and legal certainty to a degree among OTC derivatives contracting parties. ${ }^{16}$

\section{Central counterparties' core functions}

Clearinghouses' primary duties can be summarized in: (i) the execution of trades, which is achieved by interposing themselves as third-parties in the trade transaction, (ii) the management of situations where one of the parties goes bust; risk-management is a multifaceted task since, as has been documented in the aftermath of the crisis, the bankruptcy of even one systemically important financial institution (SIFI) can have onerous repercussions not only for its counterparts, but for the economy as a whole, (iii) the development of organizational features that can prevent risky situations, through the sharing of losses. ${ }^{17}$

${ }^{12}$ For historical narratives of clearinghouses, see Neal L. Wolkoff and Jason B. Werner, "The History of Regulation of Clearing in the Securities and Futures Markets, and Its Impact on Competition," Rev. Banking \& Fin. L. 30 (2010): 313; Randall S. Kroszner, Can the Financial Markets Privately Regulate Risk?: The Development of Derivatives Clearinghouses and Recent Over-the-Counter Innovations, 31 J. MONEY, CREDIT \& BANKING 596, 598-604 (1999).

${ }^{13}$ Mainly because of the (i) overwhelming attention they have attracted and the ensuing regulatory overhaul in the aftermath of the 2008 crisis, and the (ii) transnational nature of these transactions, which implies that trading parties and clearinghouses from utterly different jurisdictions can be involved. For a narrative of the crisis' unfolding and the role of derivatives trading see Lewis, Michael. The Big Short: [inside the Doomsday Machine]. New York: Simon \& Schuster Audio, 2010.

${ }^{14}$ Bank for International Settlements, Statistics: OTC derivatives, Semiannual OTC derivatives statistics, available at http://www.bis.org/statistics/d5_1.pdf.

${ }^{15}$ For detailed analysis of over-the-counter derivatives nature, classifications, and risks embedded in derivatives contracts see Norman M. Feder, "Deconstructing over-the-Counter Derivatives," Colum. Bus. L. Rev., 2002, 677.

${ }^{16}$ See K. Jomadar, The ISDA Master Agreement-The Rise and Fall of a Major Financial Instrument (Westminster Bus. Sch.; Univ. of Westminster Sch. of Law, Working Paper, 2007), available at http://papers.ssrn.com/sol3/ papers.cfm?abstract id= 1326520; See also Frank Partnoy, ISDA, NASD, CFMA, and SDNY: The Four Horsemen of Derivatives Regulation? 1-11 (Univ. of San Diego Sch. Of Law, Working Paper No. 39, 2002).

${ }^{17}$ Craig Pirrong, The Economics of Central Clearing: Theory and Practice 5-6 (ISDA, Discussion Paper Series No. 1, 2011), available at http://www2.isda.org/functional-areas/research/discussion-papers/, 6-8. 


\section{CCP's novation in OTC derivatives}

The necessity for the creation of clearinghouses originated in the trading parties' need for certainty when it comes to respecting the terms of the contract and minimizing the trading risks. ${ }^{18}$ The way central counterparties mitigate the risks associated with over-the-counter derivatives transactions, and inject more safety in financial markets is intertwined with the fact that CCPs become a party of the swaps themselves; the clearinghouse realizes that by novating the contract of each party of the trade to itself. The process by which the CCP turns into the counterparty to the original contracting parties to a derivatives trade is called novation. In more detail, in the novation procedure Party $\mathrm{X}$ transfers the rights and obligations that are laid down in its contract with Party Y to the clearinghouse, and Party Y acts the same way. It can be deduced that clearinghouses interpose themselves in the middle of an off-exchange derivative contract and generate bilateral commitments with both contracting parties.

Internalizing counterparty risk and the systemic stability mandate

There are two types of risk that clearinghouses encounter. CCPs' role is primarily to insulate the individual parties from the downturn scenario in which one of the parties becomes incapable of living up to the trading obligation it has assumed. This type of risk is called counterparty risk and clearinghouses emerge as shields against counterparty default via the mechanics of risk management they develop. The crafters of financial regulation around the world have catered to the general principles in event of a default waterfall. ${ }^{19}$ The clearinghouses are the ones to complement and make operational these principle-based rules. The second type of risk that CCPs have been designed to mitigate in the domain of OTC derivatives is systemic risk. ${ }^{20}$ Managing systemic risk is vital for the stability of global markets. But contrary to counterparty risk, systemic risk is almost impossible to harness and forecast. ${ }^{21}$ The question is how clearinghouses can contribute to the endeavor of containing systemic risk, or more accurately phrased, how they can limit the systemic exposures generated by the trading of OTC derivatives. Taken as granted that CCPs furnish a prophylactic cushion when parties assume risks from the derivatives transactions that can make them dangerously vulnerable, if an event where either one or the other party fails transpires, ${ }^{22}$ they intend to promote systemic stability to the degree that the failure of one financial firm due to its over-the-counter derivatives trading activity will not have a chain-effect that can impact related markets, at least with respect to the obligation it has undertaken in that score.

\section{Mutualizing losses}

Mutualizing losses by clearinghouses on the one hand and market participants on the other gives rise to an insurance-like society, the principles of which, such as adverse selection and moral hazard, are embedded in the OTC derivatives clearing business by defining the players' operations. Since large

${ }^{18}$ For a detailed law and economics analysis of clearinghouses and a critical stance of the regulatory policies that circumscribe them, see Yesha Yadav, "Problematic Case of Clearinghouses in Complex Markets, The," Geo. LJ 101 (2012): 387.

19 See infra for the EU.

${ }^{20}$ Systemic risk has been defined as the risk which derives from an event with widespread economic ramifications (i) that can generate the failure of markets or institutions, or (ii) that can cause significant losses to financial institutions, and leads to increases in the cost of capital or decreases in its availability has been defined as systemic risk. See Steven L. Schwarcz, Systemic Risk, 97 GEO. L.J. 193, 204 (2008).

${ }^{21}$ For intriguing analyses of the inherent complexities of financial markets and proposed remedies, see Iman Anabtawi \& Steven L. Schwarcz, Regulating Systemic Risk: Towards an Analytical Framework, 86 NOTRE DAME L. REV. 1349, 1368-70 (2011).

${ }^{22}$ The case of AIG which had to be bailed-out by the federal government because significant Wall Street players, who had large exposures in OTC credit derivatives markets, depended on its protection in the credit default swaps market, underscores what regulators had in mind while crafting the regulatory reforms and the new role for clearinghouses in OTC derivatives transactions. See Mike Konczal, Interview: Gary Gensler Explains How Financial Reform is Going, WASH. POST WONKBLOG, Oct. 19, 2013 
losses are mutualized among the clearinghouse and its members, and CCPs have developed sophisticated schemes for the posting of collateral by their members for any derivatives contract on the basis of reflections acquired by their holistic understanding of the markets, ${ }^{23}$ it can be inferred that market participants are incentivized to make more prudent decisions in their trading business that avoid excessive risk-taking. The CCPs regulatory perimeter in the US is imperfect and literature has criticized the clearinghouses' concentration of risk that they have assumed turning into SIFIs themselves, and the ensuing absence of regulatory tools in case they go into bankruptcy. ${ }^{24}$ In the EU, the Commission has already initiated a legislative proposal for the resolution and recovery of CCPs, ${ }^{25}$ to encounter such problematic scenarios.

\section{The EU Regime on CCPs}

\section{The EU way: Taking clearing seriously}

EMIR's most important features are discussed in that section, and emphasis is placed on the provisions that pertain to aspects of cross-border trade.$^{26}$ Principally, the possibility of a clearinghouse established outside the $\mathrm{EU}^{27}$ to provide its clearing services in the EU. The legal and economic uncertainties caused by Brexit and the role of City, as a global financial hub, pose additional questions about the clearinghouse business and the way forward. At that stage, there is no warranty about the trading relation that the divorcees are going to strike, and all are on the table. ${ }^{28}$ The block of the merger between the Frankfurt Exchange and London Stock Exchange by the European Commission, on the $29^{\text {th }}$ of March 2017, was justified on the grounds of restraining competition from the clearing of bonds and single stock equity derivatives markets. ${ }^{29}$ Although third time was not apparently the charm for the case of the involved parties and their conglomeration, the dynamics that Brexit exerted increased uncertainty about the future, decreased the parties' determination to conclude the deal, and ultimately were a catalyst in the EC decision's outcome. Additionally, another controversial issue that will dominate the negotiations between the EU and the UK is the degree and the terms of which euro-denominated products will be cleared in the UK, after it leaves the block. ${ }^{30}$ This subject is not new, as the European Central Bank

${ }^{23}$ Felix B. Chang, "The Systemic Risk Paradox: Banks and Clearinghouses under Regulation," Columbia Business Law Review, 2014, 14-06. Cf. Zachary J. Gubler, The Financial Innovation Process: Theory and Application, 36 DEL. J. CORP. L. 55, 89-93 (2011).

${ }^{24}$ See Mark J. Roe, “Clearinghouse Overconfidence," 101 California Law Review, 1641 (2013); Julia Lees Allen, "Derivatives Clearinghouses and Systemic Risk: A Bankruptcy and Dodd-Frank Analysis," Stanford Law Review 64 (2012): 1079; Stephen J. Lubben, "Failure of the Clearinghouse: Dodd-Frank's Fatal Flaw," Va. L. \& Bus. Rev. 10 (2015): 127; Hester Peirce, "Derivatives Clearinghouses: Clearing the Way to Failure," Clev. St. L. Rev. 64 (2016): 589-747.

${ }^{25}$ See Proposal for a Regulation of the European Parliament and of the Council on a framework for the recovery and resolution of central counterparties and amending Regulations (EU) No 1095/2010, (EU) No 648/2012, and (EU) 2015/2365, and ESMA's opinion, delivered on the $5^{\text {th }}$ of April 2017, on that proposal available at https://www.esma.europa.eu/sites/default/files/library/esma70-151-222_esma_opinion_on_ccp_rr_0.pdf.

${ }^{26}$ Trade in services, services suppliers, and the modes of supply, under WTO Law, are some of issues that are analyzed and critically assessed below.

${ }^{27}$ Also referred to as a 'third-country CCP'" in the EU jargon.

${ }^{28}$ After withdrawing from the EU, the worst-case scenario for both parties, that used to be part of the European single market is to conduct their trade on WTO terms. For an analysis of all the scenarios that are on the table for cross-border trade in financial services see Thomas J. Reid, David Polk \& Wardwell LLP, 14 April 2017, The Law \& Brexit XI, Harvard Law School Forum on Corporate Governance and Financial Regulation, available at https://corpgov.law. harvard.edu/2017/04/14/the-law-and-brexit-xi/.

${ }^{29}$ For the European Commission's Press release on the blocking of the proposed merger between LSE and Deutsche Boerse see http://europa.eu/rapid/press-release_IP-17-789_en.htm, and for the Decision see http://ec.europa.eu/compe tition/elojade/isef/case_details.cfm?proc_code=2_M_7995.

${ }^{30}$ See https://www.ft.com/content/936b2f3c-04b7-11e7-ace0-1ce02ef0def9. 
(ECB) has sought in the past to have a say in that process, because of the monetary aspects associated with these transactions. ${ }^{31}$ To conclude, as it can be projected at this point a probable scenario in respect of UK CCPs' treatment, after its exit from the union, is the EMIR equivalence regime. ${ }^{32}$ This framework is analyzed below, and evaluated from a WTO law perspective in section V.

\section{The EMIR ground-rules and its extraterritorial dimension}

\section{EMIR's architecture}

As a response to the G20 agreement in Pittsburgh, ${ }^{33}$ the European Commission drafted a proposal for a regulation on CCPs and its justification lied in the fact that clearinghouses have admittedly turned into 'systemically relevant' financial institutions. ${ }^{34}$ This point can be reaffirmed by EMIR's condition that CCPs must have a permanent and available initial capital of at least 7.5 million EUR, ${ }^{35}$ which implies that the stakes are high. Indeed, the role of clearinghouses for financial market infrastructure is indispensable and EMIR has taken over prescribing their realm in EU legislation. EMIR came into force in August 2012 and the provisions relating to CCPs are structured as follows: Title I delineates the subject matter and scope, and furnishes definitions, Title II lays down a clearing obligation regarding OTC derivatives that have been 'declared subject to the clearing obligation' by the European Securities and Markets Authority (ESMA). ${ }^{36}$ Moreover, the duties of parties to derivatives trades are mandated: Title III sets out the requirements for authorizing EU Member States' CCPs and recognizing those from third-countries. In Title IV the regulatory requirements for central counterparties are developed as they pertain to their membership criteria, posting of collateral, default funds, governance and more. Title $\mathrm{V}$ reflects on interoperability arrangements between CCPs. Some regulatory highlights of EMIR are touched upon briefly, and then its extraterritorial reach is discussed.

\section{Instruments}

The role of margin pledged by counterparties to deliver their clearing obligation is fundamental for the operation of the central counterparties and at the same time constitutes a guarantee for the parties' commitment to the swap. When it comes to the initial collateral that parties to an OTC derivatives contract must post, EU law mandates that it shall be calculated on the basis of $99.5 \%$ confidence interval and a five-day liquidation period. ${ }^{37}$ With regard to the quality of the margin, EMIR prescribes that it

\footnotetext{
${ }^{31}$ For the European Court of Justice (ECJ) judgement, see Case T-496/11, UK v. ECB (Location policy); for an assessment, see Heikki Marjosola, "Missing Pieces in the Patchwork of EU Financial Stability Regime? The Case of Central Counterparties," Common Market Law Review 52, no. 6 (2015): 1491-1527.

${ }^{32}$ Ultimately, this political decision will be subject to the balance that the negotiations between the EU and the UK define in the domain of financial services.

${ }^{33}$ G20 leaders gathered to confront the challenges that arose for the world economy due to the 2008 financial crisis. See http://www.g20.utoronto.ca/2009/2009communique0925.html.

${ }^{34}$ European Commission, Proposal for a Regulation of the European Parliament and of the Council on OTC derivatives, central counterparties and trade repositories (September 2010), $\operatorname{COM}(2010) 484$ final, see at http://ec.europa.eu /internal_market/securities/docs/isd/mifid/COM_2011_652_en.pdf, paragraph 4.3.3.

${ }^{35}$ EMIR, Art. 16 (1).

36 The imposed clearing obligation and its procedure are stipulated in Art. 4-6 of EMIR, and Commission Delegated Regulation (EU) 2015/2205 of August 2015, Commission Delegated Regulation (EU) 2016/592 of 1 March 2016, and Commission Delegated Regulation (EU) 2016/1178 of June 2016 further supplement EMIR with respect to regulatory technical standards (RTS) on the obligation to clear certain types of OTC derivatives.

${ }^{37}$ RTS, Commission Delegated Regulation (EU) NO 253/2013 of 19 December 2013 supplementing EMIR, Art. 24(1) and 26(1).
} 
must be highly liquid and must not contain any credit or market risk. ${ }^{38}$ There is neither a positive nor a negative list for the type of collateral, and discretion is left to clearinghouses to make that call. Since their own funds are on the line, CCPs ought to be quite conscious about the collateral decisions they make on their discretion in that regard.

Another aspect of the European Regulation on CCPs is the step-by-step procedure in case a counterparty goes bust. EMIR has designed a set of rules under the name 'default waterfall' ${ }^{39}$ that stipulate how the CCP's assets shall cover the losses that might be generated in the scenario of a clearinghouse member's default. Before having recourse to any other resources, CCPs shall exhaust the collateral posted by the member at-issue.$^{40}$ If the posted margin does not suffice to cover the losses incurred, the next step is acquiring the bankrupt member's own contribution to the default fund. ${ }^{41}$ If the margin and contribution of the member are not sufficient, clearinghouses are required to use their own resources before they can use the contributions of non-defaulting members from the default fund. ${ }^{42}$ This provision is crafted to address the danger of moral hazard that can arise in the context of the central counterparty's excessive risk taking in the clearing business. ${ }^{43}$

\section{EMIR's jurisdictional scope}

The jurisdictional scope of EMIR is principally enshrined in the following two circumstances: (i) the clearing obligation is applicable to OTC derivatives transactions entered into by a financial counterparty or a non-financial counterparty in the EU and a third-country institution, under the condition that the non-EU entity at issue be subject to the clearing obligation if it was established in the European Union; ${ }^{44}$ and (ii) the clearing obligation and the criteria for reducing risk are applicable to transactions between third-country entities that would be subject to the clearing obligation if they were EU entities, under the condition that their transaction has a 'direct, substantial and foreseeable effect within the EU' ${ }^{45} \mathrm{Scott}$ identifies 3 'extraterritorial' triggers in EMIR that reinforce the global reach of EU law; ${ }^{46}$ namely, the effects doctrine, anti-evasion, and transactions that involve a counterparty from the EU block. The EU jurisprudence is familiar with the effects doctrine, because it was devised by the EU courts in the era of competition case law, and has recently been examined by the CJEU in the Intel case. In EMIR it is the first time that the effects doctrine is expressly embodied in the legislation of the European Union. ${ }^{47}$

The extraterritoriality that EMIR provisions embody are justifiable because there is a nexus with either European entities and/or an appreciable effect to the EU single market. Regulators, after witnessing the diffusing effects from the trading of derivatives in foreign jurisdictions, opted to hedge their own by

\footnotetext{
${ }^{38}$ EMIR, Art. 46(1).

39 Ibid, Art. 45.

40 Ibid, Art. 45(1).

${ }^{41}$ Ibid, Art. 45(2).

42 Ibid, Art. 45(3). This step is also called 'skin-in-the-game' because the CCP is tasked with using its own dedicated resources, thereby incentivizing the CCP to engage in prudential risk management to avoid losses.

${ }^{43}$ An analogy can be drawn with the excessive risk-taking behaviors that SIFIs indulged in throughout the global financial crisis. For instance, by lowering the collateral standards in order to attract more OTC derivatives traders in their business and earn more fees could generate a valid moral hazard scenario, if the 'skin-in-the-game' provision were not in place.

${ }^{44}$ EMIR Art. 4(1) (a) (iv).

${ }^{45}$ EMIR, Art. 11(12). This provision resembles with Art. 722(d) DFA.

${ }^{46}$ Scott see above (no ), page 1363.

${ }^{47}$ In the realm of EU law, the effects doctrine has traditionally existed in the jurisprudence of European Courts when it comes to ruling competition law cases. Pursuant to this doctrine domestic competition law is applicable to foreign economic actors, located outside the state's jurisdiction, if their conduct causes an effect within the domestic territory. See for example Case T-102/96, Gencor v Commission, [1999] ECR II-753, para 90, and Case C-413/14 P, Intel Corporation Inc. v Commission, [2017] EU:C:2017:632, para 65.
} 
broadening their regulatory grip over third-countries' operations. This type of financial regulation with the 'extraterritorial edge' stems from the need to avoid deregulation or jurisdiction cherry-picking of trading activities, which can result in onerous effects not only for market participants, but for taxpayers as well. It is understandable to use past market failures as benchmarks to counteract future problematic scenarios, and accordingly to overhaul the regulatory apparatus; this is what the EU and many other regulators around the globe, including the US, have done. However, it is not understandable to pass laws that inhibit international trade and are at odds with WTO law disciplines and commitments, even with states with whom you have alongside pushed forward and implemented the G20 commitments. The EMIR third-country recognition regulatory framework implies inconsistencies hard to reconcile with WTO Law. Its main characteristics are elaborated subsequently.

\section{The 'equivalence' regime for third-country central counterparties}

Pursuant to EMIR Article 25, under the title 'Recognition of a third-country CCP', clearinghouses from non-EU Member States can provide clearing services in the Union only after they have been recognized by the European Securities and Markets Authority (ESMA). The principal criteria that need to be fulfilled beforehand are: (i) that the CCP in question shall already be authorized in its home country, and 'is subject to effective supervision and enforcement ensuring full compliance with the prudential requirements applicable in that third country'; ${ }^{48}$ (ii) that the European Commission furnishes its equivalence assessment, via an implementing act; ${ }^{49}$ (iii) that the anti-money laundering and financing of terrorism laws in the third country are equivalent to the ones of the EU; ${ }^{50}$ and (iv) that the regulatory authority of the third-country has concluded cooperation arrangements with ESMA. ${ }^{51}$ It should be stressed that equivalence determinations may be unilateral acts, but at the same time it should not be disregarded that they are endorsed within a scheme of collaboration between the EU and the thirdcountries at issue.

ESMA maintains that these requirements together will ensure that recognized third-country clearinghouses do not disrupt the orderly functioning of European financial markets, do not have a competitive advantage against those of the EU, and will provide appropriate investor protection. ${ }^{52} \mathrm{At} \mathrm{a}$ first glance, the abovementioned criteria for the recognition of non-EU clearinghouses appear to be clear and to serve their purposes. But do the ends justify the means? And maybe does the EU 'equivalence regime' instead of disfavoring service providers from third-country jurisdictions, give rise to disproportionate and unjustifiable disadvantages for CCPs from other non-EU countries? The design of the equivalence regime is not an EU innovation; the US has similar provisions enshrined in DFA under the name 'substituted compliance.' The rationale is the same: to extend recognition to CCPs from foreign jurisdictions, but only to those whose regulatory frameworks are trustworthy to provide similar standards as the domestic laws do, which accordingly would avoid potential market failures in their own jurisdictions.

\footnotetext{
48 EMIR, Art. 25 (2) (b).

${ }^{49}$ EMIR, Art. 25 (2) (a). Additionally, the actual wording is of significance, see EMIR Art. 25(6): The Commission may adopt an implementing act under Article 5 Regulation (EU) No 182/2011, determining that the legal and supervisory arrangements of a third country ensure that CCPs authorized in that third country comply with legally binding requirements which are equivalent to the requirements laid down in Title IV of this Regulation, that those CCPs are subject to effective supervision and enforcement in that third country on an ongoing basis and that the legal framework of that third country provides for an effective equivalent system for the recognition of CCPs authorized under third-country legal regimes. It is deduced from that provision that the Commission's assessment of third-countries' regulatory frameworks is threefold.

${ }^{50}$ EMIR, Art. 25 (2) (d).

${ }^{51}$ EMIR, Art. 25 (2) (c).

${ }^{52}$ See ESMA/2012/379, Draft Technical Standards for the Regulation on OTC Derivatives, CCPs and Trade Repositories, par. 126.
} 
Before the final text of EMIR was proposed by the European Commission, complex and contentious discussions about how the equivalence regime should be formulated took place in Brussels. The WTO commitments were supposedly borne in mind in the legislative process. ${ }^{53}$ To date, a little more than 5 years from the day that EMIR was first applied, 28 third-country CCPs from 14 third-countries, established in Australia, Hong-Kong, Japan, Singapore, South Africa, Canada, Mexico, Switzerland, South Korea, the USA, the United Arab Emirates, India, Dubai, and Brazil have been recognized by ESMA, and offered services in the European Union. ${ }^{54}$ Additionally, it is worth mentioning that after a period of troublesome discussions and multiple oppositions, only a year ago was the Title VII DoddFrank regime deemed equivalent by the European Commission. ${ }^{55}$

What does the number of recognized third-country regimes and clearinghouses tells us about the effectiveness of the equivalence regime? To my understanding, it implies that it is an undoubtedly cumbersome process, but when it attains its finalité, it can provide clarity and legal certainty to the parties doing business with the EU. But what about the third-countries, whose regimes are not qualified as equivalent? The EU's regime permits clearing trade flows with only 14 jurisdictions outside the EU, discouraging to a large degree cross-border trade. Neither the European Commission nor EMSA, which furnishes the technical advice, based on which the Commission's equivalence assessments transpire, have unlimited resources and the capacity to engage into high-complex analyses of third-country clearinghouse regulations. The ones who pay the price of the measure and face foreclosure are minor jurisdictions. For the sake of this argument, consider the numerous central counterparties that have applied for recognition, while their domestic regime has not yet qualified as 'equivalent', and as a result might need to wait for an undetermined number of years before they can provide their clearing services in the EU. ${ }^{56}$

Furthermore, one of the questions that arises in the context of the new regulatory frameworks on OTC derivatives from both sides of the water and the extraterritoriality they promulgate in their realm pertains to whether the 'equivalence' and the 'substituted compliance' regimes generate a new type of asymmetric compliance which can generate disruptions in the trading process. ${ }^{57}$ The extraterritorial effects of the EU legislation on CCPs in conjunction with the respective extraterritoriality laid down in the laws of a third-country can potentially disrupt international trade of OTC derivatives. More concrete examples are furnished infra, but the fact remains that international private law norms are not sufficient to resolve that conundrum. The rationale behind the 'equivalence' assessments is intertwined with the safeguard that operating central counterparties conducting business between the EU and third-countries

${ }^{53}$ See Lucia Quaglia, "The Politics of 'Third Country Equivalence' in Post-Crisis Financial Services Regulation in the European Union,” West European Politics 38, no. 1 (2015): 167-84.

54 These 28 clearinghouses are ASX Clear (Futures) Pty Ltd, ASX Clear Pty Ltd, HKFE Clearing Corporation Limited, Hong Kong Securities Clearing Company Limited, OTC Clearing Hong Kong Limited, SEHK Options Clearing House Limited, Japan Securities Clearing Corporation, Tokyo Financial Exchange Inc, Central Depository (Pte) Limited, Singapore Exchange Derivatives Clearing, ICE Clear Singapore, JSE Clear, ICE Clear Canada, Natural Gas Exchange Inc, Canadian Derivatives Clearing Corporation, Asigna Compensacion y Liquidacion, SIX x-clear AG, Korea Exchange Inc, Chicago Mercantile Exchange Inc, ICE Clear Credit LLC, Minneapolis Grain Exchange Inc, ICE Clear US Inc, Dubai Commodities Clearing Corporation, The Clearing Corporation of India Ltd, Nasdaq Dubai Ltd, Japan Commodity Clearing House Co. Ltd, BM\&FBovespa S.A, and Nodal Clear LLC.

${ }^{55}$ For the Commission - Press release, see http://europa.eu/rapid/press-release_IP-16-807_en.htm, and for the Commission Implementing Decision, see http://eur-lex.europa.eu/legal-content/EN/TXT/PDF/?uri=CELEX:320 $16 \mathrm{D} 0377 \&$ from $=\mathrm{EN}$.

${ }^{56}$ CCPs from Argentina, Malaysia, Chile, Turkey, Israel, Taiwan, and Thailand among others have applied for recognition. See ESMA's list for further details, available at https://www.esma.europa.eu/sites/default/files/library/ list_of_applicants_tc-ccps.pdf.

${ }^{57}$ For some frame ideas of the possible effects of the new status quo created by the OTC derivatives regulations around the world, see John Philpott, 'Equivalence' - The key to Global OTC swaps reform, OTC Space, available at http://www.theotcspace.com/2015/10/11/\%E2\%80\%98equivalence\%E2\%80\%99-\%E2\%80\%93-key-globalotc-swap-reform. 
are on a level - high standard - playing field. This would imply that their costs are comparable; as such, CCPs from one or the other side would not need to incur additional compliance costs. However, even as market certainty for cross-border OTC derivatives transactions is promoted, liquidity is injected, and no market disruptions arise in the event that a third-country CCP is recognized, under EMIR article 25, the opposite can be invoked when an 'equivalence' regime is not struck, as in the case of the minor jurisdictions which do not have an equivalence deal with the EU yet.

\section{Financial Regulation and International Economic Law: what's the catch?}

In the absence of International Financial Regulation, domestic regulators are vested with the responsibility of crafting their own national legislations. ${ }^{58}$ Positive integration of financial regulations through harmonization is impossible and each country must regulate its own territory. Even when countries implement the international standards that IOs put forward, there is always space for discrepancies among different legal orders for a plethora of reasons, ranging from divergences in legal cultures, to internal pressures in serving national interests. Additionally, regulators around the world are supposed to be in close collaboration with one another in order to front-run future crises, and not indulge in self-interest. ${ }^{59}$ In the advent of the regulatory overhaul, as a response to the deficiencies that the crisis exposed, literature has witnessed a tendency exercised by countries with 'regulatory leverage' to promote regulations which either have an extra-territorial effect or which incentivize other countries to follow their lead and raise the bar accordingly, instead of adopting a 'race to the bottom' approach. ${ }^{60}$

The underlying rationale for that extraterritorial type of financial regulation comes with the hindsight earned from the hard lessons of the past. The financial markets' interconnectivity necessitated more radical approaches by regulators. However, the absence of international 'hard' law rules for financial regulation is still an unresolved issue. Given that financial services are predominantly provided today in a cross-border context, potential inconsistencies in standards and regulatory asymmetries in the realm of clearinghouses can be worrisome. Fortunately, financial regulation is not the sole legal branch applicable in the era of financial transactions with a transnational element. What the current analysis is missing at this stage is the stance of WTO disciplines and specific commitments with respect to trade in financial services. WTO law prescribes the rules of the game, when there are measures adopted by WTO Members ${ }^{61}$ that affect trade in services.

Consequently, the General Agreement on Trade in Services (GATS) provisions capture the regulatory measures that affect trade in clearing services. In practical terms, this means that when an international service provider engages in a trading or post-trading activity with another market participant who is a WTO Member, they both step into the realm of an additional set of rules which mandates trade in

58 The existence of International Organizations (IOs), such as the Bank for International Settlements, IOSCO, and OECD among others, is crucial for promulgating the soft law standards that national regulators are suggested to adopt. However, in numerous occasions soft law standards do not suffice to counteract the irregularities they have been designed to address. For the role of soft law in financial regulation, see C. Brummer, "Why Soft Law Dominates International Finance--and Not Trade," Journal of International Economic Law 13, no. 3 (2010): 623-43.

59 John Gapper, An Imperfect Plan for Fixing the Next Crisis, FIN. TIMES (Nov. 12, 2014, 5:12 PM), http://www.ft.com/intl/cms/s/0/9d71113e6-69a2-11e4-8f4f-00144feabdcO.html.

${ }^{60}$ For a thought provoking body of literature reflecting on the extraterritoriality of financial regulation and the way international financial regulation can be approached, see John C. Coffee Jr, “Extraterritorial Financial Regulation: Why ET Can't Come Home," Cornell L. Rev. 99 (2013): 1259; Yesha Yadav and Dermot Turing, "The Extraterritorial Regulation of Clearinghouses," Journal of Financial Regulation 2, no. 1 (March 2016): 21-55; Chris Brummer, "How International Financial Law Works (and How It Doesn't)," Geo. LJ 99 (2010): 257; Joanne Scott, "The New EU 'Extraterritoriality'," Common Market Law Review 51 (2014): 1343, John Philpott, 2013, 'Extraterritoriwhat!?', Blogspot: johnphilpott.com, available at https://johnphilpott.com/2013/09/28/extraterritoriwhat/.

${ }^{61}$ WTO Members represent all the world's major economies, including the EU countries, the US, China, Russia, India, and Japan among others. As of 29 July 2016, the World Trade Organization counts 164 Members, available at https://www.wto.org/english/thewto_e/whatis_e/tif_e/org6_e.htm. 
financial services under WTO law. Trade in financial services constitutes a significant part of the trade flows of the EU and the US, and the GATS offers its own legal system that places national legislations under scrutiny, assuming commitments have been entered. ${ }^{62}$ WTO law, as an international legal order, provides for uniformity in its rules and can serve as the missing piece needed to resolve this paper's puzzle. Additionally, with Article 50 triggered by the UK on the $29^{\text {th }}$ of March $2017,{ }^{63}$ and the ongoing Brexit negotiations it is even more thrilling to explore the rules the WTO puts forward to regulate trade in financial services in order to extrapolate deductions for the scope of this paper. Financial services are an industry with special interest for both the UK and all its trading partners, either from within EU block or across the Atlantic.

\section{The GATS' ubiquity in clearing OTC derivatives}

This section develops as follows; firstly, the WTO Law relevant toolkit - the GATS - is presented in order to prepare the ground for the analysis on how the financial regulatory issues in question and international trade law are at a crossroads. Further on, the analysis of the two legal disciplines interactions in the field of OTC derivatives clearinghouses is developed, and both financial stability and trade protectionism/liberalization reflections are taken into consideration. Ultimately, the provision on Domestic Regulation is approached.

\section{The GATS 'playbook'}

\section{What is the GATS?}

The GATS ${ }^{64}$ is the first multilateral and legally enforceable agreement that covers investment and trade in services. Marchetti and Mavroidis provide for an insightful analysis of the dynamics that led to the "genesis" of the GATS as the consequence of a progressive political compromise. ${ }^{65}$ The GATS is applicable to "measures by Members affecting trade in services". ${ }^{66}$ The definition of a "measure' is very broad in the GATS, encompassing any type of action in any possible form taken by a Member. The scope of the GATS covers both the treatment extended by a Member to another Member's services and service suppliers. ${ }^{67}$ In the same vein, a 'measure' by a Member 'affecting trade in services' includes measures regarding: (i) the purchase, payment, or use of a service; (ii) the access to and use of, in connection with the supply of a service, services which are required by those Members to be offered to the public generally; and (iii) the presence, including commercial presence, of persons of a Member for

62 The WTO dispute settlement system has encountered and the relevant adjudicating bodies have ruled cases pertaining to trade in financial services in the past; see China-Electronic Payment Services, WT/DS413/9/Add.1 (12 July 2013), and more recently, Argentina-Financial Services, WT/DS453/Add. 1 (14 April 2016).

${ }^{63}$ Article 50 of the Treaty on the Functioning of European Union (TFEU) represents the 'divorce clause' from the EU block, and has been historically activated for the first time by an EU Member State, the UK to initiate the proceedings for leaving the EU. See https://www.ft.com/content/22c0d426-1466-11e7-b0c1-37e417ee6c76?emailId=58db9b25dce7e 800041e3ff2\&segmentId=3d08be62-315f-7330-5bbd-af33dc531acb.

${ }^{64}$ See for general literature, B. Hoekman and P. Sauve, 'Liberalizing Trade in Services', World Bank Discussion Paper No 243, 1994, 30; A. Sapir, 'The General Agreement on Trade in Services: From 1994 to the Year 2000' (1999), Journal of World Trade, 33(1), 51.

65 See J. A. Marchetti and P. C. Mavroidis, “The Genesis of the GATS,” European Journal of International Law 22, no. 3 (August 1, 2011): 689-721.

${ }^{66}$ GATS Article I:1; Cf. Report of the Appellate Body, European Communities-Regime for the Importation, Sale and Distribution of Bananas (EC-Bananas), WT/DS27/AB/R, 9 September 1997, para. 220; Panel Report, Mexico-Telecoms, par. 7.41.

${ }^{67}$ Panel Report, EC - Bananas III, par. 7.320; Appellate Body Report, EC - Bananas III, par. 227. 
the supply of a service in the territory of another Member. ${ }^{68}$ Subsequently, it can be safely deduced that an EU Regulation touching upon the conditions for the provision of clearing services in OTC derivatives transactions on a transnational level, definitely qualifies as a 'measure' under the GATS scrutiny.

\section{GATS 4 modes of supply}

The GATS reference point system and the commitments assumed by Members is contingent upon the concept of 'trade in services'. The definition of trade in services in the GATS mirrors the four modes of supply through which a service can be provided. ${ }^{69}$ The four modes of supply that the Agreement identifies are the following: ${ }^{70}$ (i) cross-border supply, (ii) consumption abroad, (iii) commercial presence, and (iv) temporary movement of natural persons. Possible inconsistencies that might arise between modes of supply in the realm of trade in financial services are encountered in detail below. And yet the role of the four modes of supply is not only to exemplify how trade in services can be conducted, but rather to generate binding effects based on Members' undertaken commitments in specific services sectors. The role of Schedules of Specific Commitments (hereinafter called 'Schedules') that WTO Members have assumed is essential for the GATS architecture because it is the ultimate mechanism to foster trade liberalization in services trade. ${ }^{71}$ Although, asymmetric in nature, because of the latitude provided to Members to inscribe Market Access, National Treatment, and Additional Commitments in their Schedules for all services sectors based discretionally on their national preferences, it is the determinant in appraising to what degree Members engage in liberalization policies. At the same time, it provides for legal certainty, transparency, and predictability because of its legally binding nature for foreign service suppliers with regard to the treatment they are to receive in the Members' territories for the services sectors in question. ${ }^{72}$

\section{The GATS core objective}

To attain a holistic understanding of the GATS constellation it is crucial to realize that the objective that defines the variable geometry of the Agreement, is the progressive liberalization of trade in services. ${ }^{73}$ Progressive liberalization can only be materialized through political compromise and perseverance on the benefits deriving from international trade, and ultimately that being reflected on the Members' Schedules. This understanding can serve as a landmark to underscore the 3 fundamental components upon which the GATS is built: namely, (i) the framework Agreement, which sets out the relevant general obligations and disciplines, the specific commitments and all the relevant procedures deemed necessary

${ }^{68}$ GATS Article XXVIII(c); however, it shall be borne in mind that the list prescribed in the Agreement is indicative according to the Appellate Body Report, EC - Bananas III, par. 220.

${ }^{69}$ For literature on the subject, see P. Chang, G. Karsenty, A. Mattoo \& J. Richtering, 'GATS, the Modes of Supply and Statistics on Trade in Services', 1999, Journal of World Trade 33(3), 94.

${ }^{70}$ Enshrined in GATS Article I:2.

${ }^{71}$ Pursuant to GATS Article XX:3, Schedules are an integral part of the GATS. The practical implication of that provision is that, while each Member's Schedule enshrines the commitments undertaken by a Member, the Members' Schedules altogether translate into an agreement among all WTO Members. Appellate Body Report, EC-Computer Equipment, par. 109; Appellate Body Report, US - Gambling, par. 159-160. For literature on the subject, I. Van Damme, 'The Interpretation of Schedules of Commitments', 2007, Journal of World Trade 41(1), 1; Rudolf Adlung et al., "FOG in GATS Commitments - Why WTO Members Should Care,” World Trade Review 12, no. 01 (2013): 1-27.

72 In the WTO jargon, when a Member extends full commitment to a services' sector that is scheduled, there should be no barriers for foreign service suppliers and the word 'None' shall be mentioned. In juxtaposition to full commitment, when a Member opts for maintaining its flexibility in posing market access and national treatment restrictions, then 'Unbound' is the term to be inscribed in the relevant sector in the Schedule.

${ }^{73}$ See GATS Preamble, second recital. To embolden that objective, the Panel Report, US - Gambling, par. 6.313 reads: progressive liberalization entails including more sectors in Members' schedules and reduction or elimination of limitations, terms, conditions, and qualifications on market access and national treatment through successive rounds of negotiations'. 
to accompany them and ultimately to promote trade in services $;{ }^{74}$ (ii) the 8 Annexes,${ }^{75}$ which cover both horizontal and sector-specific issues; and (iii) the Members' Schedules. The dimension of the GATS that matters the most in the context of clearing OTC derivatives is trade in financial services. The GATS has its own instruments and mechanics when it comes to regulating trade (Annex on Financial Services) on the one hand, and inscribing Members' commitments (Understanding on Commitments in Financial Services) on the other for financial services sectors.

\section{The GATS \& trade in financial services}

\section{What is the Annex and the WTO jurisprudence take on clearing?}

The Annex on Financial Services caters for a lex specialis that further elaborates on the general GATS rulebook and better puts the financial services sectors into perspective. It is a useful companion in the effort to interpret the role of CCPs for clearing OTC derivatives in a transnational playground. In accordance to Article XXIX, ${ }^{76}$ the GATS Annex is treaty text and therefore generates legally binding effects for all WTO Members. ${ }^{77}$ It provides definitions for both "financial services" 78 and "financial service suppliers". ${ }^{79}$ These determinations can serve as useful guides in the pursuit of delineating the role of clearinghouses in the domain of WTO law. The financial service that clearinghouses for OTC derivatives provide in the context of the GATS Annex is associated with the: Settlement and clearing services for financial assets, including securities, derivative products, and other negotiable instruments. ${ }^{80}$

The WTO adjudicating bodies have not yet been challenged to rule on any case relating to the service of clearing financial instruments. But on the subject of electronic payment services, the Panel has offered useful interpretation to Article 5(a)(xiv) of the Annex. The issue that the Panel had to shed light upon in the China-Electronic Payment Services related to which service was at stake in the course of the case. On the one side the US advocated in favor of characterizing the electronic payment services under 5(a)(viii) of the Annex. On the other China argued that 5(a)(xiv) was the most appropriate venue for them. The parties of the dispute debated hotly on this ostensibly minor issue, because China's undertaken commitments hinge on which services sub-sector they have been assumed for. Consequently, it is inferred that the categorization of a service under either 5(a)(viii) or 5(a)(viii) was an issue of high relevance for the course of the litigation in question because it differentiated the scope of China's commitments. ${ }^{81}$ In the Panel's words 'subsector (xiv) encompasses the clearing and

74 The obligations and disciplines are discussed below, with emphasis on the aspects necessary to surround the observations and make the argument this paper pronounces on more comprehensible.

75 The 8 Annexes are the following: Annex on Article II Exemptions; Annex on Movement of Natural Persons Supplying Services under the Agreement; Annex on Air Transport Services; Annex on Financial Services; Second Annex on Financial Services; Annex on Negotiations on Maritime Transport Services; Annex on Telecommunications; Annex on Negotiations on Basic Telecommunications.

76 GATS Article XXIX stipulates that 'The Annexes to this Agreement are an integral part of this Agreement."

77 Pursuant to Article II:2 of the WTO Agreement, the agreements and associated legal instruments included in Annex 1, e.g., the GATS, are integral parts of the WTO Agreement, binding on all Members.

78 Annex on Financial Services, par. 5(a).

79 Ibid. par. 5(b).

${ }^{80}$ Ibid. par. 5(a)(xiv).

${ }^{81}$ Panel Report, China - Electronic Payment Services, par. 7.163. Regarding the difference of opinions between the US and China on the nature of services in question, the Panel ruled that: ... Our conclusion is also based on the important practical differences between, on the one hand, the clearing and settlement of financial assets like securities and, on the other hand, the clearing and settlement of payment transactions. Hence, it is our view that retail payment instruments listed in subsector (d) of China's Schedule are not "financial assets" within the meaning that term has in subsector (xiv) of the Annex and, therefore, transactions based on the payment instruments listed in subsector (d), included payment cards, are not cleared 
settlement of financial instruments sharing essentially the same characteristics as securities, derivative products and other negotiable instruments. More particularly, we consider that subsector (xiv) covers the clearing and settlement of financial instruments which have investment attributes, grant ownership rights and yield clearing and settlement of payment transactions ${ }^{\prime}{ }^{82}$ This clarification by the Panel adds precision to the financial services sub-sector upon which this paper focuses.

\section{The Understanding and its crucial role for the EU commitments on financial services}

Contrary to the Annex, the Understanding does not constitute an integral part of the GATS. The rationale behind the Understanding lies in WTO Members' willingness to enable further liberalization on trade in financial services sectors; this is portrayed by the idiosyncrasy of the rules and disciplines enshrined in its text. It should be emphasized that the Understanding is not binding to all Members, who are not obliged to assume their commitments based on the principles promulgated by it. Only the WTO Members that opt for adopting the Understanding in the financial services section of their Schedules are bound. ${ }^{83}$ Consequently, the Understanding is of voluntary nature; it hinges on Members trade policy decision making processes to what degree the Understanding's liberalizing effects extend to the multilateral trading system. ${ }^{84}$ The Understanding bestows in fact "'a sort of a formula approach to scheduling commitments under Articles XVI, XVII, and XVIII of the GATS with regard to financial services' ${ }^{85}$ When it comes to cross-border trade, the Understanding's reach extends to both modes 1 and 2 of the GATS. ${ }^{86}$ The obligations that emanate from the scope of mode 1 are narrower than of mode 2 because of the number of financial services subsectors' coverage. However, in the domain of financial services there is an inherent challenge in discerning mode 1 from mode 2, and this can have an adverse effect on the interpretation of Members' Schedules and ultimately their sectoral commitments by giving rise to ambiguities. This discourse takes place in section $\mathrm{V}$.

and settled under subsector (xiv). See Bernard Hoekman and Niall Meagher, "China - Electronic Payment Services: Discrimination, Economic Development and the GATS," World Trade Review 13, no. 02 (April 2014): 409-42.

82 Panel Report, China - Electronic Payment Services, par. (?)

${ }^{83}$ Pursuant to GATS Article XX:3, "Schedules of specific commitments shall be annexed to this Agreement and shall form an integral part thereof." Subsequently, it can be deducted that the Members that have undertaken their commitments in the financial services sector in accordance with the Understanding cater for the binding character of the Understanding through their Schedules.

${ }^{84}$ That viewpoint can be reaffirmed by the Preamble of the Understanding which reads in (ii) that 'it does not prejudice the right of any Member to schedule its specific commitments in accordance with the approach under Part III of the Agreement.' In that text 'Agreement' is the GATS, and 'Part III' is the venue where the rules for specific commitments that WTO Members can assume in their Schedules are laid down. The Members that have voluntarily adhered to it are the following: Australia, Bulgaria, Canada, Czech Republic, European Communities (EC15), Hungary, Iceland, Japan, Lichtenstein, New Zealand, Nigeria, Norway, Slovak Republic, Sri Lanka (excluding insurance), Switzerland, Turkey, and the United States.

85 WTO, Council for Trade in Services, Committee on Trade in Financial Services, S/C/W/312, S/FIN/W/73, 3 February 2010 , par. 36, p. 10.

${ }^{86}$ In respect of mode 1, the Understanding mandates that a Member shall allow non-resident suppliers of financial services to provide, "'as a principal, through an intermediary or as an intermediary, and under terms and conditions that accord national treatment", a specific number of services: (a) insurance of risks relating to maritime shipping and commercial aviation and space launching and freight, with such insurance to cover any or all of the following: the goods being transported, the vehicle transporting the goods and any liability arising therefrom; and goods in international transit, (b) reinsurance and retrocession and the services auxiliary to insurance, such as consultancy, actuarial, risk assessment, and claim settlement services, (c) provision and transfer of financial information and financial data processing as referred to in subparagraph 5(a)(xv) of the Annex and advisory and other auxiliary services, excluding intermediation, relating to banking and other financial services as referred to in subparagraph 5(a)(xvi) of the Annex. When it comes to what appears to be mode 2, the commitments have a broader scope; Members "shall permit its residents to purchase in the territory of any other Member the financial services indicated" in the previous paragraph, and additionally all banking and other financial services listed in subparagraphs 5(a)(v) to (xvi) of the Annex on Financial Services. 


\section{The universe of Domestic Regulation in the GATS}

\section{GATS Article VI: a pervasive trade-law tool (in hibernation)}

The very purpose of the GATS is to foster liberalization of trade in services and to ensure that the Agreement sets out a number of obligations and disciplines that are vested with that responsibility. ${ }^{87}$ Article VI is one of them, but exists in a hybrid form because some of its provisions are intimately linked to the Members' Schedules. The rationale behind Domestic Regulation was to introduce a mechanism that would warrant that Members' regulations would not be inequitable, excessively interventionist, or inhibit trade disproportionately to the desired outcomes. ${ }^{88}$ It should be stressed that liberalization in services is confined by non-tariff barriers that take the form of Members' internal regulations. ${ }^{89}$ Nevertheless, the Members' regulatory autonomy is prescribed in the GATS Preamble, ${ }^{90}$ and can serve as a valuable means of WTO provisions' interpretation by illustrating the negotiators' intentions. ${ }^{91}$ It can be inferred that governmental protectionism ${ }^{92}$ can be entrenched in Members' regulations and subsequently, can be deemed, on a case-by-case basis, unlawful under WTO law.

Article VI revolves around the way domestic regulations are designed, administered and applied, and furnishes (i) legally binding provisions of procedural nature, ${ }^{93}$ (ii) a mandate to deploy a multilateral discipline for qualification, technical standards and licensing requirements, and (iii) a substantive obligation of transitional nature to flesh out the future discipline's core elements. The application of Members' domestic measures shall reflect on the principles embedded in the GATS, and principally on fairness, as an expression of non-discrimination, ${ }^{94}$ openness, in the form of transparency, ${ }^{95}$ and on negotiated commitments. ${ }^{96}$ The Panel has delineated the universe of Article VI in the US - Gambling report. ${ }^{97}$

${ }^{87}$ The terms obligations and disciplines is derived from the title of Part II of the Agreement, 'General Obligations and Disciplines' which is in juxtaposition to Part III, 'Specific Commitments', exactly because they highlight the GATS' asymmetric geometry, which is based on the Members' possibility to inscribe their own commitments in their Schedules. The provision in question, Article VI, constitutes a combination of the two.

${ }^{88}$ For the background of the Uruguay Round negotiations on Domestic Regulation, see P Delimatsis. (2010). Concluding the WTO services negotiations on domestic regulation-hopes and fears. World Trade Review, 9(04), 643-673.

${ }^{89}$ For a categorization of barriers to trade in services see B Hoekman and CAP Braga, 'Protection and Trade in Services: A Survey'. PRWP No 1747, 1997, 5; RM Stern, 'Quantifying Barriers to Trade in Services', 2000, 2.

90 The forth recital of the GATS Preamble reads: Recognizing the right of Members to regulate, and to introduce new regulations, on the supply of services within their territories in order to meet national policy objectives and, given asymmetries existing with respect to the degree of development of services regulation in different countries, the particular need of developing countries to exercise this right.

91 Appellate Body Report, US - Shrimp, par. 153.

92 To protect domestic production against foreign competition, market distortions, and political trade interventions. See J Bhagwati, 'The Pure Theory of International Trade: A Survey' (1964, 74(293) The Economic Journal 18.

93 Panel Report, US - Gambling, par. 6.432.

94 Non-discrimination is the guiding principle in the WTO system, and MFN is the most representative example in the GATS. For literature on the subject see A. Mattoo, 'MFN and the GATS' in T. Cottier and P. Mavroidis (eds.), Regulatory Barriers and the Principle of Non-Discrimination in World Trade Law, 2000, 51, and for an up-to-date opinion reflecting on today's US administration see AO Sykes, CP Bown https:/www.wsj.com/articles/most-favored-nation-rule-hurtsimporters-limits-u-s-trade-1495733394.

95 See GATS Article II.

${ }^{96} \mathrm{P}$ Delimatsis. International trade in services and domestic regulations: necessity, transparency, and regulatory diversity. Oxford University Press, 2007, 95.

${ }^{97}$ Panel Report, US - Gambling, par. 6.316: Members maintain the sovereign right to regulate within the parameters of Article VI of the GATS. Members' regulatory sovereignty is an essential pillar of the progressive liberalization of trade in services, but this sovereignty ends whenever rights of other Members under the GATS are impaired. The Appellate Body reaffirmed the Panel's finding. See Appellate Body Report, US - Gambling, par. 235. 


\section{The WTO Law consistency of the EU regime on third-country clearinghouses}

\section{Cross-border supply vs Consumption abroad: the stakes for trade in clearing services}

Given that Members' Schedules are determinants in the GATS geometry, this analysis embarks on the relevant EU Schedule ${ }^{98}$ in order to trace the EU's inscribed commitments in clearing services and subsequently, to underscore the existence of legal ambiguities that are hard to disregard and reconcile with the existing legal machinery provided by the text of the Agreement and WTO case-law. Pursuant to the EU Schedule in place for the financial services sector: The Communities and their Member States undertake commitments on Financial Services in accordance with the provisions of the 'Understanding on Commitments in Financial Services.' Supra, the main features of the Understanding are discussed. The following reveals the identified inconsistencies between the modes of supply in financial services, to highlight the degree of legal ambiguity and diverging solutions that might arise in the context of interpreting the Understanding and Members' Schedules.

Traditionally, the four modes of supply, as they are enumerated in Article I:2 of the GATS, are segregated in two broader categories that pertain to whether the service supplier provides her service within or outside the territory of the Member, of which relevant commitments are examined. Consequently, the service supplier's territorial presence makes all the difference in that score. The two broader categories that can be discerned are, modes 1 and 2, which imply that the service supplier is outside the Member's territory, and modes 3 and 4, which require the service supplier's presence within the Member's territory. The Trade in Services Division of the WTO has attempted to provide clarity in the modes of supply. To that end, for cross-border supply the fact that the supplier is not present in the territory where the service is provided is underlined and telecommunications, mail, or international transport are referred to as textbook cases, while consumption abroad is intertwined with the 'movement of the consumer', although in a number of occasions at it is mentioned in the Guidelines, and is demonstrated later, that is not necessary. Tourism services are an example of this. ${ }^{99}$ Below, I explain the intricacies in the supply of financial services and the emerging problems for the GATS legal interpretation.

Financial services are an economy sector characterized by high complexities due to the breadth of activities it involves, ranging from retail banking services to trading ETF securities and to the truly globalized nature of the markets. Additionally, since it is a network industry, ${ }^{100}$ financial services operate on technical platforms that vary on the basis of the services provided. Information and telecommunication networks, for example, offer necessities and infrastructure, while contributing to economic growth. The fast pace technology has adopted the last few decades, has required the financial industry to adjust accordingly. The role of the Internet is crucial in that equation. Who could have imagined two decades ago that today we can carry out bank transactions anywhere using a smartphone? The emergence of fintech reveals emphatically the relevance of new technologies in the world of finance, and may be the answer to the high concentration witnessed in the sector by traditional service providers. However, that discussion goes beyond the scope of this paper, and attention shall instead be placed in the cross-border element of financial transactions. The forthcoming analysis approaches the international clearing of OTC derivatives and aspires to disentangle the GATS' modes of supply existing conundrum in the case of divergence in the level of the Members' commitments.

Regulatory issues are intentionally left out to avoid unnecessary variables and to shed light exclusively on the discourse of modes 1 and 2. First, over-the-counter derivatives transactions, such as IRS for example, are consummated between two parties, $A$ and $B$. Once the swap passes to the post-trade phase

\footnotetext{
${ }^{98}$ For the EU Schedule, see https://www.wto.org/english/tratop_e/serv_e/serv_commitments_e.htm

${ }^{99}$ World Trade Organization, Trade in Services, S/L/92, 28 March 2001, Guidelines for the Scheduling of Specific Commitments Under the General Agreement on Trade in Services (GATS), p. 8-10.

100 See N Economides. "The economics of networks." International journal of industrial organization 14.6 (1996): 673-699.
} 
and clearing services are required, another party comes into play, namely the clearinghouse $(C C P)$. As explained, the $C C P$ at that stage, interposes itself between parties $A$ and $B$ and becomes the buyer to every seller and the seller to every buyer. Therefore, it is held that the clearing service supplied that is the analysis' focal point is none other than the service provided by the $C C P$ to the parties that conclude the swap, namely $A$ and $B$. For the sake of simplicity in this example, the two parties are from the same WTO Member and each party's relations to the clearinghouse are not examined. ${ }^{101}$ Since the service supplier and the service at stake have been defined, the next step is to supplement the scenario with an international dimension, so that the GATS modes of supply discussion becomes relevant. The Member's level of liberalization enshrined in its commitments is added as the next step.

The parties to the swap deal of the example, $A$ and $B$, are institutional investors incorporated in the EU. They decide to clear their derivative contract with a clearinghouse incorporated in the US. Before testing the example on each mode of supply, it shall be reiterated that derivative traders are essentially investment banks and funds that have an international line of business and are not restricted by territorial borders, supplying their services across frontiers. Moreover, clearinghouses are selected on the grounds of their efficiencies for particular securities swaps and the lower costs for the parties, and engage in business with international elements by default. That said, when it comes to mode 1 - cross-border supply - things appear to be quite clear cut. The clearing service in question is provided from the territory where the service supplier (the $C C P$ ) is situated into the territory where the contracting parties reside, accordingly from the US to the EU in our example. Before moving on to mode 2, it should be underscored that the nature of the Internet, as an international electronic distribution channel for the supply of financial services, narrows the gap - or even cuts the dividing line - between mode 1 and 2 precisely because it does not reflect on the natural presence of the consumer. More accurately, 'once the physical presence of the consumer ceases to be a benchmark for determining the place of delivery of a service, it becomes extremely difficult to determine in an unambiguous manner where a service is delivered'. ${ }^{102}$ Consumption abroad is the mode of supply that is contingent upon the consumer's orientation across the globe; this is why the issue is so complex in such a context. To conceptualize the clearing services with more clarity, consider a pre-step like wire-transfers and the role of international payment systems; when capital flows across the globe between different WTO Members and their service suppliers, does the location in which the order is made play any role? The same applies to clearing services: it is not likely that $A$ and $B$ are going to physically move into the US, the territory of the $C C P$, to acquire its services because electronic channels are omnipresent and tasked with consummating numerous transactions. Clearing OTC derivatives would be one example of this. Consequently, it is imperative for both the Members and the WTO dispute settlement system to address this issue by providing clarification for the sake of legal certainty.

Presuming that the inscribed commitments in a Member's Schedule in a financial services sub-sector are the same for both modes 1 and $2,{ }^{103}$ the issue immediately becomes redundant. Nevertheless, in the case of the Understanding things are far from straightforward between the commitments for the two modes of supply, and ultimately for the legal and practical implications of the GATS architecture. Emphasizing once again that the EU has assumed its commitments on the basis of the Understanding, the degree of liberalization for its clearing services hinges on the mode for which they are assumed. In the case of mode 1 , clearing services ${ }^{104}$ are not accorded national treatment, while in the case of mode

${ }^{101}$ In several occasions the parties to a derivatives contract that must be centrally cleared are not members of any clearinghouse, which impedes their access to them. Accordingly, the parties need to acquire the services of other institutions that are members, to ensure access to the CCP's services. This perplexes our example, and that is why it is left out of the discussion. For a comprehensive analysis, see D Turing, Clearing and Settlement, Bloomsbury, 2016, p. 44-49.

102 This Note underlines the problem in the distinction between the two modes of supple in the GATS, and provides for the background discussions that have taken place under the auspices of the WTO thus far. S/FIN/W/73 P13-14

103 For example, None/None or Unbound/Unbound.

104 As they are described in the Annex Paragraph 5(a)(iv): Settlement and clearing services for financial assets, including securities, derivative products, and other negotiable instruments. 
2, they are covered by the scope of 'full commitment'. At this point, it is evident that the services in question can generate different legal consequences from a GATS perspective that can resonate in other branches of law, depending on the interest of the parties. Since neither the WTO dispute settlement system nor the Members have shed light on that score until now, the writer adopts the view that clearing over-the-counter derivatives services between the EU and WTO Members are supplied via mode 2 and the subsequent analysis evolves on that premise. This approach is adopted because in addition to being closer than the alternative to the objective of trade liberalization, it constitutes a fruitful framework to assess the WTO-consistency of the EU regulation on clearinghouses. The forthcoming sections aspire to trace and elaborate on the regulation's inherent problems from a GATS perspective.

\section{Transparency: and its problematic aspects in 'third country's CCPs recognition process}

Transparency is one of the fundamental WTO law disciplines ${ }^{105}$ that reflects any country's openness towards their trading counterparts, and is essentially one of the general obligations that are applicable erga omnes in services trade. ${ }^{106}$ Transparency, as it is enshrined in GATS Article III, relates to the Members' mandate to furnish predictability in the multilateral trading system, by publishing the laws with respect to trade in services, notifying the Council for Trade in Services for new measures, and finally addressing other Members' inquiries. This mandate is generic in nature, and lex specialis exists in GATS Article VI Par. 5(a)(i) which encounters the concept of transparency in the domain of qualification procedures, technical standards and licensing requirements. This implies that the procedural aspects of EMIR for recognizing third-country clearinghouses, are better captured by the content of this provision. The next paragraphs seek to elaborate on the EU regime's transparency issues.

First, Article VI:5, which encompasses a substantive legal obligation of transitional character, is analyzed. Paragraph 5 is of provisional nature exactly because it is 'pending the entry into force of the disciplines developed in these sectors pursuant to paragraph 4', notably twenty-two years after the entry into force of the GATS. The architecture of this provision is dependent upon Members' specific commitments. This is an expression of the progressive liberalization principle entrenched in the GATS. In the realm of this provision, the negotiators' reluctance to reinforce the content of the paragraph can be explained by the fact that paragraph 4 was supposed to cover all services sectors, regardless the Members' Schedules, regarding qualification requirements, technical standards, and licensing requirements. Therefore, they designed that provisional paragraph to accommodate a minimum qualitative set of standards of market access for the internal legal frameworks of WTO Members that have made commitments, until the point in time that negotiators will have determined an agreement in respect of their mandate under paragraph 4 . One feature of this provision that may seem perplexing at first glance is the one of 'nullification or impairment'. This concept is at the epicenter of the WTO judicial system and it should be approached accordingly. There is a presumption of nullification or impairment, pursuant to Article 3:8 of the Dispute Settlement Understanding (DSU), when there is a breach of an obligation assumed under one of the agreements covered by the DSU. This mechanism allocates the burden of rebutting the existence of nullification or impairment on the respondent. ${ }^{107}$ The possible misunderstanding emerges because in addition to violation complaints, such as the ones described above, there are the so-called non-violation complaints (NVC) which are not based on WTO Members' obligations. As the GATS prescribes its own NVC provision, ${ }^{108}$ it may sound redundant to reiterate the need for a causal link between an obligation's infringement and the effect of nullification or impairment. In my opinion, a sensible explanation to address that issue, can be that the drafters of the

\footnotetext{
105 For an analysis of the principle's evolution see Mavroidis, Petros C., and Robert Wolfe. "From sunshine to a common agent: the evolving understanding of transparency in the WTO." Brown J. World Aff. 21 (2014): 117.

106 See GATS Article III.

107 Appellate Body Report, US - Wool Shirts and Blouses, par. 14; Appellate Body Report, EC - Hormones, par. 98.

108 See GATS Article XXIII:3.
} 
Agreement included these terms to add emphasis on the abovementioned presumption, and not to add another NVC provision in the GATS.

Furthermore, an additional reference point to assess whether the substantial obligation enshrined in Article VI:5(a) is respected, exists in (b). Utilizing the international standards put forward by relevant international organizations can prove crucial during that assessment. ${ }^{109}$ The GATS drew inspiration from Article 2.5 of the TBT Agreement and Article 3:2 of the SPS Agreement, which also use IO's standards to assess the necessity and reasonableness of particular measures. Financial regulations around the world heavily rely on standards developed by IOs, such as the Basel Committee, OECD, and IOSCO. Nevertheless, membership to such organizations is not usually open to all WTO Members and thus, their standards could not be used as filters in this context. Of course, a more detailed analysis would be required that exceeds the scope of this paper.

The criteria that are enumerated in order to formulate a complaint in violation of Article VI:5 follow: (i) a Member has a commitment in a specific services sector; (ii) this Member imposes licensing, or qualification requirements, or technical standards in this sector; (iii) the application of the measures nullifies or impairs the specific commitments assumed; (iv) the nullification or impairment transpires in a way that is not consonant with the conditions of transparency, objectivity, and necessity stipulated in Article VI:4(a-c); ${ }^{110}$ and (v) such nullification or impairment could not have been reasonably anticipated by that Member when the specific commitment was undertaken. ${ }^{111}$ Along these lines, it should be said that since the analysis rests on the premise that EU Schedule mode 2 full commitment for clearing services exists, EMIR's transparency aspects shall be examined, as the first two criteria, namely (i), and (ii) are now fulfilled, in order to discover whether they impair the EU's commitments.

The EU in its attempt to design a robust and resilient regulatory scheme for clearinghouses, while seeking to avoid the contagion of any systemic failure originating outside EU markets, has indulged in adopting measures that can be contested before the WTO adjudicating bodies in respect of transparency issues of substantive nature. Namely, WTO Members, whose CCPs have not acquired a recognition, and subsequently are unable to ply their services in the EU, can invoke that the EMIR regime is lacking objective and transparent criteria with respect to the licensing requirements. This can be substantiated by the fact that the main criteria on which ESMA and the Commission base their assessments on are not crystal clear due to numerous factors. The third-country recognition procedure is driven by motives relating to the clearinghouse's jurisdictional leverage in the supranational arena. The Implementing Acts $^{112}$ that the Commission adopts reinforce the regulatory framework's lack of transparency exactly

109 The GATS further explains the term 'relevant organizations', as the ones that are open to membership to at least all Members of the WTO. This criterion generates legal consequences of magnitude, since it furnishes additional set of standards that can prove essential in WTO judiciary's scrutiny of Members' domestic regulation. However, it should be mentioned that the standards developed by organizations such as the OECD, with closed membership, are not deemed as appropriate benchmarks in that provision.

${ }^{110}$ Article VI:4 reads: With a view to ensuring that measures relating to qualification requirements and procedures, technical standards and licensing requirements do not constitute unnecessary barriers to trade in services, the Council for Trade in Services shall, through appropriate bodies it may establish, develop any necessary discipline. Such disciplines shall aim to ensure that such requirements are, inter alia: (a) based on objective and transparent criteria, such as competence and the ability to supply the service; (b) not more burdensome than necessary to ensure the quality of the service; (c) in the case of licensing procedures, not in themselves a restriction on the supply of the service. Article VI:5 has been defined as '... an effort to operationalize the objectives stated in VI:4, the most important of which was the necessity test', according to the WTO Secretariat in WTO, WPDR, 'Report on the Meeting Held on 11 May 2001', S/WPDR/M/11, 7 June 2001, par. 29.

111 The GATS entered into force on January $1^{\text {st, }} 1995$, and this category reflects on the measures in place by that time.

112 Which are based on Article 5 of Regulation No 182/2011 and are highly dependent upon the technical advice on third countries regimes that ESMA produces. The Commission Delegated Regulation (EU) No 153/2013 of 19 December 2012 supplementing EMIR with regard to regulatory technical standards on requirements for central counterparties, on the basis of art. 2 sets out particular conditions in respect of CCP's target member states, types of instruments cleared, its shareholders, margin and collateral, stress tests, compliance, record, outsourcing arrangements, segregation arrangements, membership criteria, and interoperability arrangements. Although numerous criteria are put forward, the argument of that 
because of the nature of their determinations with respect to (i) 'effective supervision and enforcement' that the CCPs are subject to in third countries, and (ii) third countries' 'legally binding requirements which are equivalent' to EMIR's requirements. These 2 criteria prescribed in EMIR are abstract. This paper's argument lies in the fact that the most important parameter is the way they are assessed by the European Commission, because the requirements themselves leave large room for discretion in the appraisal phase. Although, these criteria as they are articulated in the text of the Regulation seem quite transparent at first glance, a second reading in conjunction with ESMA's advice and the Commission's Acts generates further questions. These questions emanate from the discrepancy among WTO Members' financial regulatory frameworks, which can be justified on the basis of different levels of the legislature's expertise, separate historical backgrounds, divergent economic interests, and most importantly different legal cultures. Thus, the points on effective supervision and enforcement, and legally binding requirements that are equivalent are not models of clarity because they are not benchmarks that third countries and their clearinghouses can rely on, to supply their services in the EU. Rather, they promulgate some criteria that the EU institutions construe arbitrarily, and confusion emerges from the discrepancies in the assessment of different jurisdictions.

The lack of transparency element that resides in EMIR regulation is at odds with the GATS Article VI Paragraph 5(a)(i) provision because it is trade restrictive on the grounds that service suppliers from 'third countries' suffer the loss of opportunity to access the European market. The lack of transparency is particularly in evidence in the absence of explicit guidelines that explain what 'third countries' effective supervision and enforcement of clearinghouses might entail, and what would be the parameters for the equivalence assessment, given that financial regulations across the globe are inherently disparate. A careful reading of the Commission's Implementing Acts in tandem with ESMA's technical advice reveals that conducting this type of analyses is far from being an easy task, due to the complexities and internal characteristics of 'third countries' legal orders. Regardless of how challenging the task is, more transparent criteria should be put forward for the sake of predictability in order to inform WTO Members with regard to the procedural steps that the EU institutions undertake and the gravity of particular regulatory aspects. Empirical research on the existing Implementing Acts and technical advice would highlight the trends that are followed, but that, too, exceeds the scope of this paper. Transparency is intended to furnish openness to trade in services, and the regulatory framework at issue does not attain that objective, in the context of trade in clearing services in the EU.

In addition to EMIR's transparency problems, which have been highlighted in the realm of the GATS reference system, the role of the European Commission should be examined as the next step. The Commission plays a critical role in the 'third country' clearinghouses licensing procedure, and that is why the mechanics it employs should be filtered from an international economic law perspective. For clearinghouses from third-countries to provide their services in the EU a Commission's equivalence assessment is presupposed, as it is demonstrated supra. Therefore, the Commission's practice should be in line with the WTO rules of the game, at least when the third-country CCPs seeking to provide their services in the EU are WTO Members. The next subsection underscores the Commission's procedural aspects of discretionary abuse, which are based on the judgement calls it has to make due to the lack of unlimited resources.

\section{The European Commission's excessive discretion in the 'equivalence' determination}

When it comes to the process that the Commission follows to conduct its equivalence assessments of 'third-countries' regimes relating to clearinghouses pursuant to EMIR, it should be underlined that the WTO rules' scrutiny in that situation address both the way that the measure at-issue is administered and the measure as such. The Commission's role is to examine the regulatory frameworks of 'third countries', and while using ESMA's technical advice, to make its deductions regarding the levels of the

paper is based on the fact that there is no transparency on the methodology that these criteria are assessed by the EU institutions. 
regime's equivalence with EMIR. As stated above, the task to be recognized by ESMA and ultimately provide their services in EU Member States is of magnitude for 'third-county' clearinghouses. Subsequently, is a stepping stone in that recognition process and it has a huge impact on the market access of service providers from 'third-countries'. Given that 'third-countries' are to the highest extent WTO Members, the measure's WTO-consistency is critical, and this paper places emphasis on the EU's GATS commitments, in order to define the measure's possible unlawfulness under the rules of international economic law. The European Commission's practice in that process is excessively discretionary at the expense of numerous WTO Members.

This analysis builds again on the premise that the EU commitments on financial services are based on the Understanding, and additionally provides for a thought-provoking take regarding the modes of supply that clearing services, as they have been defined above, are supplied. The application of the equivalence assessment by the Commission can be characterized as biased against the regulatory frameworks of smaller countries, and ultimately favors the CCPs from jurisdictions that have the socalled 'regulatory leverage'. That said, the WTO dispute settlement mechanism is at the disposal of smaller countries that can initiate litigation to address the issue. In contrast to the transparency discourse, this argument is of procedural nature, and the role of the Commission is examined to reveal whether the current state of affairs is problematic from a WTO law perspective. Since this type of the Commission's behavior is not marginally onerous to any of the EU Member States, the measure has not received criticism from within. Nonetheless, when WTO Members' interests are inflicted by specific measures, an examination of the counterfactual could illuminate particular regulatory practices. In specific, GATS Article VI:1 requires the reasonable, objective and impartial administration of domestic regulation. However, the Commission's discretion does not guarantee to WTO Members the standards of due process for which they qualify. What is discretionary about the Commission's practice in the equivalence determinations is discussed next.

The first Paragraph of VI, ${ }^{113}$ is identical to Article X:3(a) of the GATT, ${ }^{114}$ and stipulates the obligation of reasonable, objective and impartial administration. As the provision's wording makes evident, this obligation is contingent upon the Members' assumed commitments in services sectors. Accordingly, it mirrors the GATS asymmetric architecture, reflecting the progressive liberalization principle, which aspires for WTO Members to widen the perimeter of their services sectors commitments. Interestingly, Article VI:1 presupposes that WTO Members, when administering their domestic legal frameworks, shall conform to certain minimum standards of due process, ${ }^{115}$ which include the notions of fairness and equity. ${ }^{116}$ This provision reinforces the norms of consistency and predictability, ${ }^{117}$ and therefore promotes good regulation standards for Members to adopt.

Subsequently, any measure that on the surface appears fair and just would come under the purview of this provision if it is de facto applied in an arbitrary, unreasonable, and biased fashion. ${ }^{118}$ This element of WTO judicial review is essential to the integrity of the multilateral trading system because it avoids governmental circumvention on the basis of the distinction between measures as applied /as such.

113 The GATS Article VI:1 mandates: In sectors where specific commitments are undertaken, each Member shall ensure that all measures of general application affecting trade in services are administered in a reasonable, objective and impartial manner.

114 The line of reasoning developed by the WTO judiciary can prove a salient guide for understanding the mechanics of the GATS Article VI:1. For an in-depth analysis bearing in mind the GATT relevant jurisprudence see P. Delimatsis, 'Due Process and 'Good"' Regulation Embedded in the GATS - Disciplining Regulatory Behaviour in Services Through Article VI of the GATS' (2007) 10 Journal of International Economic Law, p 20-28.

115 Due process is a concept intertwined with that provision; see Panel Report, EC - Selected Customs Matters, para. 7.134

116 Geza Feketekuty, 'Regulatory Reform and Trade Liberalization in Services', in Pierre Sauvé and Robert M. Stern (eds), Services 2000: New Directions in Services Trade Liberalization, above n 14, 229-30.

${ }^{117}$ Panel Report, EC - Selected Customs Matters, par. 7.431.

118 Appellate Body Report, US - Shrimp, par. 160. 
Additionally, an infringement upon the obligations mandated in VI:1 can occur as the result of an omission in a case where an obligation to act in a specific manner is imposed. ${ }^{119}$ The WTO judicial review reveals that the obligation laid down in VI:1 circumscribes and filters the administration of such measures, or on how these measures are applied in practice, ${ }^{120}$ and does not scrutinize their substantial elements. ${ }^{121}$ Admittedly this provision is procedural by nature, and it should be noted that the administration of measures should have a significant impact on the holistic administration of a Member's regulation, and not only on the course of a particular case. ${ }^{122}$

The fundamental principles of objectivity, reasonableness, and impartiality in the administration of measures pertinent to trade in services, put forward by Article VI, attempt to ensure that foreign services providers do not face unnecessary barriers by the biased or arbitrary application of domestic regulation, by WTO Members that have made commitments. A succinct view of these principles constitutes the next step. First, the reference point in the GATT for 'measures... administered in an objective manner', is uniformity, and the relevant case-law can prove a useful guide to unravel the character of this obligation. It has been held by the Panel that a WTO Member does not conform to the standards of GATT Article X;3(a), when trade operators receive differential treatment over time and in relation to other trade operators. ${ }^{123}$ Additionally, uniformity (or objectivity in the cast of the GATS) does not require identical treatment among service suppliers, ${ }^{124}$ but rather aims at laws being applied fairly, consistently and predictably. ${ }^{125}$ Although uniformity as a concept is quite difficult to discern in the context of different disputes and measures being challenged, ${ }^{126}$ equity, transparency, notice, and fairness are some of the notions that should result in the application of WTO trade-related policies. ${ }^{127}$ Second, when it comes to the criterion of reasonableness, Panel has found that practices that are neither 'in accordance with reason', 'having sound judgement', 'sensible', neither 'articulate' or 'within the limits of reason' are considered unreasonable. ${ }^{128}$ Third, in respect of impartiality the Panel has maintained that 'whenever a party with a commercial interest, but no relevant legal interest, is allowed to participate in an export transaction..., there is an inherent danger that the Customs laws, regulations and rules will be applied in a partial manner so as to permit persons with adverse commercial interests to obtain confidential information to which they have no right', ${ }^{129}$ when these situations are not counteracted.

EMIR has been in place for more than 5 years. In that period, the European Commission has furnished just 14 Implementing Acts, meaning that only 14 'third-countries' regimes on CCPs are deemed equivalent to the one of the EU. Accordingly, only clearinghouses from these 14 jurisdictions outside the EU can provide, once they are recognized by ESMA, their services in EU markets. At this stage, it

119 Panel Report, Dominican Republic - Import and Sale of Cigarettes, par. 7.379.

${ }^{120}$ Appellate Body Report, EC-Bananas III, par. 200.

${ }^{121}$ Panel Report, US - Gambling, par. 6.432; Cf for the GATT perspective, Panel Report, Argentina - Measures Affecting the Export of Bovine Hides and Import of Finished Leather (Argentina - Hides and Leather), WT/DS155/R and Corr.1, adopted 16 February 2001, par. 11.70-11.71; See Appellate Body Report, EC - Selected Customs Matters, above n 30, paras 200201.

122 See Panel Report, United States - Anti-Dumping Measures on Certain Hot-Rolled Steel Products from Japan (US - HotRolled Steel), WT/DS184/R, adopted 23 August 2001, para 7.268.

${ }^{123}$ Panel Report, EC - Selected Customs Matters, above n 24, para 7.123.

${ }^{124}$ See Panel Report, Argentina - Hides and Leather, above n 29, para 11.84.

125 See Panel Report, Argentina - Hides and Leather, above n 29, para 11.83. See also Panel Report, EC -Selected Customs Matters, above n 24, para 7.108.

${ }^{126}$ See Panel Report, EC - Selected Customs Matters, above n 24, para 7.127

1277.490

${ }^{128}$ See Panel Report, Dominican Republic - Measures Affecting the Importation and Internal Sale of Cigarettes (Dominican Republic - Import and Sale of Cigarettes), WT/DS302/R, adopted 19 May 2005, as modified by the Appellate Body Report, WT/DS302/AB/R, paras 7.385-7.388.

${ }^{129}$ See Panel Report, Argentina - Hides and Leather, above n 29, para 11.100. 
should once again be reiterated that such a challenging task requires reasonable time. Additionally, due to existing financial stability considerations, the process becomes even more complex. ${ }^{130}$ Nonetheless, the result is trade-restrictive and limits the EU market to numerus clausus clearinghouses. At first glance, that may seem justified from a GATS perspective because of the existence of the PCO; however, the way the Commission carries out its equivalence assessments raises questions of a lack of impartiality and objectivity. First, the European Commission seems to indulge in the 'cherry-picking' of the jurisdictions that admittedly have strong clearinghouses that can prove mutually beneficial in their course of business for both EU Members and 'third-countries', so it is sensible from an economic perspective. Second, priority is given to the countries that have a 'regulatory leverage', in the sense that bigger countries are assumed to craft better regulations, and therefore it would be easier for the EU to proceed with the examination of their regimes. It is demonstrated supra that as of 8 June 2017, 29 service suppliers outside the EU can provide clearing services in European markets, but strangely they only originate from countries with strong 'regulatory' leverage. Since there are no guidelines on how the Commission examines particular jurisdictions, questions of impartiality emerge. Especially as CCPs from third-countries with insignificant 'regulatory leverage' apply, but are unable to furnish their services due to the Commission's lack of Implementing Act. ${ }^{131}$ Thus, what is discretionary about the Commission's role in the equivalence determinations is principally the fact that it prioritizes certain jurisdictions over others.

This paragraph seeks to demystify the Commission's behavior in that context. The first and most obvious answer is that both the European Commission and ESMA, which provides the technical assistance, lack the capacity and the resources to conduct the assessment of all 'third-countries' regulatory frameworks. This is understandable, considering the many complexities included in such determinations, alongside the number of 'third-country' jurisdictions. If presumably the first point reflects a part of reality, the next step in order to justify the Commission's practice is to understand the balancing test between the EU's economic interests on the one hand, and considerations of fairness, stability, and WTO law, among others, on the other. Therefore, the Commission ends up favoring the countries that fulfil the abovementioned criteria, and so the EU's regime falls short of developing a fair and equitable system for the recognition of third-country clearinghouses from a WTO perspective.

\section{Conclusion}

The task of balancing the tension between domestic regulatory objectives and international trade rules is becoming increasingly important because of the major role services play in today's economies. The focus of this paper is on the interface between EU Financial Regulation and WTO Law in the area of clearing OTC derivatives, more specifically on whether the EU Regulation of clearinghouses is consistent with WTO law. The absence of clearly defined criteria for what comprises the first two modes of supply under the GATS - mode 1 (cross-border supply) and mode 2 (consumption abroad) - in the context of trade in financial services constitutes a source of legal uncertainty for financial service providers that operate internationally. The transnational scenario of a clearinghouse providing services to market participants in different jurisdictions illustrates how such uncertainty can arise as a result of a WTO Member's Schedule having different market access commitments inscribed for modes 1 and 2 for the same financial services subsector.

The GATS consistency of the EU regime is affected by both procedural and substantive problems as a result of which the measure implemented by the EU is at odds with the EU's commitments under the WTO. The EU framework arguably falls short in not providing a sufficiently transparent set of licensing requirements for third-country clearinghouses seeking to provide their services in the EU, thus not satisfying the requirements of GATS Article VI:5 on domestic regulation. Moreover, the broad

\footnotetext{
${ }^{130}$ That can be verified by the fact that the Dodd-Frank framework, got the green light from the Commission only last year.

131 See above.
} 
discretion that the European Commission enjoys in third-country equivalence determination under EMIR infringes on the procedural obligation of reasonable, objective, and impartial administration of measures prescribed by GATS Article VI:1, because differential treatment is extended by the Commission to some jurisdictions with 'regulatory leverage' at the expense of others. EMIR's 'equivalence' regime only permits flows of clearing services among the jurisdictions that have been deemed 'equivalent' by the European Commission. The equivalence assessment that the EU carries out is a highly complex exercise that involves prudential considerations with systemic stability gravitas. However, the way these assessments are conducted can distort trade by favoring WTO Members which are deemed a priori to be better regulated jurisdictions than others. 